\title{
Konstruksi alat ukur karakter mandiri
}

\author{
Yun Nina Ekawati \\ Program Studi Psikologi, Fakultas Kedokteran dan Ilmu Kesehatan, Universitas Jambi \\ yun_nina.e@unja.ac.id \\ Nofrans Eka Saputra \\ Program Studi Psikologi, Fakultas Kedokteran dan Ilmu Kesehatan, Universitas Jambi \\ nofransekasaputra@unja.ac.id \\ Rahmadhani Islamiah \\ Program Studi Psikologi, Fakultas Kedokteran dan Ilmu Kesehatan, Universitas Jambi \\ rahmadhanimia@gmail.com
}

\begin{abstract}
ABSTRAK
Tujuan dari penelitian ini adalah untuk membuat kontruksi skala karakter kemandirian pada siswa SMA sebagai instrumen pengukuran karakter kemandirian dengan melakukan validitas konstruk menggunakan principal component analysis (PCA). Populasi penelitian ini adalah siswa Sekolah Menengah Atas (SMA). Jumlah sampel yang digunakan sebanyak 337 responden, dengan teknik pengambilan sampel dengan purposive sampling di setiap wilayah yaitu pada SMA 1 Kabupaten Kerinci, SMA Negeri 1 Tanjung Jabung Barat, SMA Negeri 5 Kota Kabupaten Tebo dan SMA Negeri 12 Kabupaten Merangin, dan SMA Negeri 1 Kota Jambi dengan rentang usia 15 hingga 18 tahun. Hasil penelitian ini menunjukkan bahwa validitas konstruk yang menggunakan analisis Principal Component Analysis dengan rotasi orthogonal dan ekstraksi varimaks menghasilkan lima faktor yang berhasil diekstraksi yang berupa komponen ketekunan, kegigihan, dan gemar belajar. Hasil uji reliabilitas konsistensi internal dengan Metode Guttman $\lambda=0.820$. Norma alat ukur menggunakan standar deviasi hipotetik baik untuk setiap komponen maupun alat ukur keseluruhan. Alat ukur ini didukung oleh validitas konstruk yang baik serta reliabilitas yang memuaskan.

Kata Kunci: Karakter Kemandirian, Kontruksi Alat Ukur, Reliabilitas, Siswa Sekolah Menengah Atas, Validitas
\end{abstract}

\begin{abstract}
The aim of this research is to create an independence character scale construction for high school students as an instrument to measure the independence character by conducting validity construct using principal component analysis (PCA). The population of this research is high school students. The number of sample used including 337 respondens, by using purposive sampling method in every regions including SMA 1 Kerinci, SMA 1 West Tanjung Jabung, SMA 5 Tebo, SMA 12 Merangin, and SMA 1 Jambi city by the age ranging from 15 to 18 years. The result of this research reveals that validity construct which using Principal Component Analysis with orthogonal rotation and varimaks extraction generated five factors extrated to be perseverance, persistance, and learning willingness. The result of reliability internal consistency by using Guttman Metode $\lambda=0.820$. The measuring tool norm by using hypothetical standard deviation for both each component and overal measurement. This measurement tool is supported by good validity constract as well as satisfaying reliability.
\end{abstract}

Keywords: High School Students, Independence Character, Measuring Instrument Construction, Reliability, Validity

Yun Nina Ekawati, email: yun_nina.e@unja.ac.id 
Jurnal Psikologi Terapan dan Pendidikan

ISSN: $2715-2456$

Vol. 1, No. 2, November 2019, pp. 143-181

\section{PENDAHULUAN}

Philips (Taqwiem, 2017) menjelaskan karakter sebagai seperangkat nilai yang memandu sistem, yang mendasari pikiran, sikap dan perilaku yang ditampilkan seseorang. Karakter secara khusus telah menjadi kajian masyarakat dunia saat ini. Tidak hanya karena karakter memiliki implikasi besar terhadap kehidupan suatu bangsa dan negara, lebih dari itu karakter merupakan salah satu fokus dalam kajian psikologi positif yang memungkinkan terciptanya kehidupan manusia yang lebih baik dengan berfokus pada kekuatan yang dimiliki individu, salah satunya melalui kekuatan karakter (Peterson \& Seligman, 2003). Hal ini dikarenakan karakter memiliki dampak terhadap cara berpikir, merasa, dan berperilaku seseorang dan menjadi kunci untuk menjadi diri yang lebih baik.

Karakter saat ini menjadi topik pembahasan dihampir setiap institusi global dunia, ini dikarenakan karakter yang berkembang dan ada pada diri individu tidak hanya berdampak pada kesejahteraan diri individu itu sendiri melainkan kesejahteraan bangsa dan negaranya. Maka dari itu saat ini hampir diseluruh negara menerapkan dan menggalakan pendidikan karakter agar dapat diimplementasikan secara tepat mulai dari lingkungan keluarga, sekolah dan instititusi masyarakat. Pengembangan implementasi pendidikan karakter juga dilakukan di Indonesia. Bahkan implementasi ini jauh telah dilakukan oleh tokoh pendidikan bangsa Ki Hadjar Dewantara yang mengembangkan konsep pendidikan sebagai keseimbangan cipta, rasa, dan karsa serta tidak hanya sekedar proses pemindahan ilmu pengetahuan saja (transfer of knowledge), melainkan juga sebagai proses transformasi nilai (transformation of value) (Haryanto, 2011).

Kemdikbud melalui program revolusi mental mengembangkan 5 nilai karakter utama yang sesuai dengan kultur budaya bangsa Indonesia yaitu karakter religius, nasionalisme, mandiri, gotong-royong, dan integritas. Penelitian ini berfokus pada pengembangan instrumen pengukuran salah satu karakter yang memiliki peran penting dalam keberhasilan individu menjalankan kehidupannya, yaitu karakter kemandirian. Webster dictionary (Meriam-Webster, 2019 http://www.merriam-webster.com) mengartikan kemandirian sebagai kebergantungan terhadap upaya dan kemampuan sendiri. Menurut Bhatia (Masrun, 1985) kemandirian merupakan perilaku yang aktivitasnya diarahkan kepada diri sendiri, tidak mengharapkan pengerahan dari orang lain, bahkan mencoba memecahkan atau menyelesaikan masalahnya sendiri tanpa meminta bantuan kepada orang lain. Pengertian-pengertian tersebut menjelaskan jika kemandirian berarti individu menggantungkan segala penilaian dan keputusan untuk mengambil tindakan dihidupnya berdasarkan referensi dirinya sendiri - ini termasuk kedalam upaya untuk mengerahkan segala kemampuan untuk meraih apa yang diinginkan dan memiliki keberanian untuk menerima dan menolak sesuatu yang tidak sesuai dengan dirinya. Ini menunjukkan bahwa kemandirian 
Jurnal Psikologi Terapan dan Pendidikan

ISSN: $2715-2456$

Vol. 1, No. 2, November 2019, pp. 143-181

memberikan otonomi bagi individu untuk dapat bertindak sesuai keinginannya - bertindak berdasarkan nilai-nilainya dan berani untuk memperjuangkannya.

Kemandirian memberikan kendali sekaligus kekuatan pada individu untuk mengatur dan mengendalikan hidupnya. Kemandirian merupakan karakter penting yang harus dimiliki oleh setiap individu. Kemandirian memberikan otonomi kepada diri individu sehingga memiliki kepercayaan terhadap diri dan kemampuannya untuk melakukan sesuatu. Kemandirian membuat individu berani memutuskan apa yang baik dan apa yang inginkan. Ini karena individu mampu mengerahkan kemampuannya untuk berpikir kritis, analitis untuk memikirkan segala hal dan mempertimbangkan segala kemungkinan baik buruk atas tindakan apa yang akan ia ambil. Disisi lain individu yang mandiri mengetahui apa yang ia inginkan dan berusaha keras untuk mendapatkan yang ia inginkan dengan mengarahkan semua kemampuannya. Ia gigih dan tekun dalam berusaha sehingga individu yang mandiri akan mampu menghindari kegagalan. Hal ini merupakan kekuatan sekaligus kualitas diri yang menjamin kesuksesan dan keberhasilan individu dalam menjalankan kehidupannya sekarang ataupun nanti.

Secara empiris, sebagian besar siswa yang masih bergantung pada orang lain dalam menyelesaikan tugas, kecenderungan untuk melihat hasil kerja orang lain adalah hal yang wajar ditemukan dalam berbagai sekolah. Tidak memiliki jiwa kompetisi, tidak berorientasi pada prestasi tertentu, membuat fenomena kenakalan remaja yang terjadi dikalangan siswa sekolah saat ini merupakan hal yang wajar. Di sisi lain, siswa saat ini memiliki gaya hidup yang hedonis - ini membuat siswa menjunjung tinggi kehidupan serba praktis dan menghalalkan setiap cara untuk mendapatkan apa yang mereka inginkan - sehingga cenderung malas untuk berusaha keras untuk mendapatkan apa yang menjadi tujuan mereka.

Krisis karakter kemandirian pada diri siswa sekolah merupakan hal buruk jika tidak dapat diatasi. Hal ini dikarenakan kemandirian sangat berarti bagi pengembangan individu, lebih lanjut bagi kemajuan bangsa dan negaranya. Jika siswa saat ini memiliki kecenderungan bergantung dengan orang lain maka bukan tidak mungkin ketidakhadiran semangat belajar dalam meraih prestasi adalah hal yang mungkin dirasakan oleh mereka. Padahal sejatinya pada masa sekolah ini mereka dapat mengimplementasikan dan mengasah diri mereka untuk berkompetisi terutama dalam bidang pendidikan (Hurlock, 2005).

Tujuan dari penelitian ini adalah untuk membuat kontruksi skala karakter kemandirian pada siswa SMA sebagai instrumen pengukuran karakter kemandirian siswa. Pengukuran ini akan membantu pihakpihak terkait dalam mengevaluasi dan memberikan intervensi yang tepat untuk pengembangan karakter mandiri baik untuk siswa maupun perencanaan kurikulum sekolah dan kelas. Disisi lain penelitian ini akan menggunakan metode principal component analysis (PCA) yang akan memberikan konstruk yang 
jelas dan konkrit mengenai karakter mandiri dan segala aspek yang membentuk atau mendasari kemandirian siswa.

Tujuan lain dari pelaksanaan kontruksi skala karakter kemandirian ini adalah untuk membuat alat ukur psikologi yang terstandarisasi. Hal itu dikarenakan belum adanya alat ukur skala karakter yang terstandar untuk mengukur atau menilai (assessment) karakter diri individu terutama siswa yang menjadi sasaran program penguatan pendidikan karakter oleh Kemendikbud. Dengan adanya skala karakter kemandirian siswa SMA diharapkan dapat menjadi skala karakter yang terstandar yang dapat mengukur karakter baik individual atau kolektif, serta yang dapat digunakan secara tunggal untuk evaluasi program pendidikan atau digunakan bersamaan dengan rangkaian tes lain sebagai bagian dari perangkat tes kepribadian individu.

\section{METODE PENELITIAN}

Penelitian ini dilakukan dengan beberapa tahapan prosedur: 1) Kontruksi alat ukur karakter mandiri, 2) Analisis properti psikometris skala. Pelaksanaan tahapan prosedur tersebut bertujuan untuk mendapatkan skala psikologi yang baik yaitu valid, reliabel, dan terstandar juga memudahkan peneliti dalam membuat analisa laporan lebih sistematis.

\section{Kontruksi Alat Ukur Karakter Mandiri}

Penetapan Konstruk, Komponen dan Indikator Perilaku

Kontruksi alat ukur diawali dengan menetapkan konstruk yang diukur yaitu konstruk karakter mandiri. Review konstruk dan komponen dilakukan melalui studi literatur yang mengacu pada beberapa buku cetak, jurnal, dan sumber literatur lainnya yang membahas mengenai karakter mandiripada remaja sekolah menengah atas. Dari studi literatur ini didapatkan beberapa komponen penyusun konstruk, diantaranya: kerja keras, kreatif, tangguh, professional, belajar sepanjang hayat, tahan banting, daya juang, dan keberanian. Masing-masing komponen diturunkan kedalam beberapa indikator perilaku yang menjadi blue print dalam penulisan item. Sebelum melakukan penulisan item maka komponen dan indikator direview terlebih dahulu oleh orang yang memiliki keahlian dibidang tersebut dalam sebuah panel diskusi melalui prosedur focus group discussion (FGD) terhadap beberapa ahli konstrak yang memahami konstrak mandiri dan ahli psikologi perkembangan manusia. Pelaksanaan FGD diperlukan mengingat konstrak yang akan dibangun didasarkan pada konsep Penguatan Pendidikan Karakter Kemdikbud yang masih umum bukanlah konsep konkrit sehingga diperlukan perumusan agar menghasilkan blue print konstrak yang padat dan konkrit yang selanjutnya akan memudahkan penulisan item. Tahapan review ahli 
Jurnal Psikologi Terapan dan Pendidikan

ISSN: $2715-2456$

Vol. 1, No. 2, November 2019, pp. 143-181

dilakukan sebelum dan setelah tahapan penulisan item. Tahapan ini akan menentukan validitas internal dari konstruk skala yang akan dibuat.

Format Penskalaan

Penskalaan merupakan proses penentuan letak kategori respon responden terhadap pernyataan item yang telah dibuat dalam suatu kontinum psikologis yang telah ditentukan (Azwar 2017). Penentuan format penskalaan ini akan menentukan bagaimana penentuan nilai yang akan diberikan. Dalam kontruksi skala ini, format penskalaan yang dipilih adalah model skala likert dengan 4 jenjang nilai, yaitu Sangat Setuju (SS), Setuju (S), Tidak Setuju (TS), dan Sangat Tidak Setuju (STS).

Penulisan Item

Setelah merumuskan komponen dan indikator konstruk kedalam blue print, peneliti membuat item sesuai dengan proporsi item yang telah ditentukan. Dalam penulisan item awal yang akan di uji coba didapatkan 24 item pernyataan yang terdiri dari item favorabel dan unfavorabel. Item yang telah dibuat di review kembali oleh peneliti, rekan peneliti, ahli konstruk, subjek sampel dan ahli tata bahasa sebelum dilaksanakan uji coba item kepada kelompok subjek. Tujuannya adalah untuk mencapai validitas logis dari alat ukur ini, apakah item telah mengungkap hal sesuai indikator yang telah ditetapkan, apakah subjek dapat mengerti apa yang dimaksud dalam item pernyataan, apakah penulisan telah sesuai dengan ejaan bahasa Indonesia yang baik dan benar.

\section{Analisis Properti Psikometris}

Analisis properti psikometris ini dilakukan setelah mendapatkan data dari uji coba alat ukur yang telah dilakukan. Analisis konstruk yang digunakan adalah uji validitas faktorial dengan metode Principal Component Analysis (PCA) rotasi orthoghonal dan ekstraksi varimaks. PCA bertujuan untuk meringkas pola korelasi antara observed variables, untuk mengurangi sejumlah besar observed variables kedalam sejumlah kecil faktor untuk memberikan definisi operasional untuk proses yang mendasarinya dengan menggunakan observed variables (Tabachnick \& Fidell, 2014). PCA melakukan analisis menggunakan korelasi terhadap sejumlah data observed variables yang memenuhi syarat analisis kemudian mereduksinya. Secara empiris teknik statistika yang digunakan dalam analisis PCA menemukan dan merangkum observed variables yang saling berkorelasi dalam satu himpunan mejadi satu komponen utama. Setiap komponen yang terbentuk akan tidak bergantung (independen) dengan komponen lainnya sehingga setiap komponen dinilai masing-masing (tersendiri) tanpa dikaitkan dengan komponen lainnya. Kemudian dilakukan ekstraksi varimaks untuk menganalisa keterbentukan faktor-faktor terhadap sekumpulan komponen yang ada. Uji Reliabilitas alat ukur dilakukan dengan menggunakan metode 
Jurnal Psikologi Terapan dan Pendidikan

ISSN: $2715-2456$

Vol. 1, No. 2, November 2019, pp. 143-181

Gutmann's. Pembuatan norma dan interpretasi yaitu dengan membuat norma hipotetik baik untuk skoring skala keseluruhan maupun skoring skala per komponen.

\section{Responden}

Subjek berjumlah 337 responden dengan teknik pengambilan sampel penelitian random sampling terhadap siswa/i sekolah menengah atas yang tersebar di Provinsi Jambi, diantaranya; SMAN 1 Kabupaten Kerinci, SMAN 1 Tanjung Jabung Barat, SMAN 5 Kabupaten Tebo, SMAN 12 Kabupaten Merangin, dan SMAN 1 Kota Jambi.

\section{HASIL DAN PEMBAHASAN}

Hasil dari pelaksanaan metode penelitian kontruksi alat ukur karakter mandiri ini adalah: 1) Skala karakter mandiri final, 2) Nilai property psikometris yang mendukung validitas dan reliabilitas karakter mandiri, serta 3) Norma dan interpretasi skala.

\section{Skala Karakter Mandiri Final}

Uji Validitas Faktorial

Komponen skala karakter mandiri final ini didapatkan melalui uji analisis properti psikometris pertama terhadap hasil data uji coba alat ukur. Uji validitas faktorial konstruk dilakukan dengan menggunakan metode analisis Principal Component Analysis (PCA). Validitas faktor merupakan validitas yang didapat melalui analisis terhadap faktor pembentuk alat ukur. Principal Component Analysis (PCA) merupakan teknik yang digunakan untuk melihat atau mengkonfirmasi faktor-faktor yang membentuk suatu konstruk skala dengan cara mereduksi komponen suatu data tanpa mengurangi karakteristik konstruk skala secara signifikan. Teknik PCA lebih dipilih karena menurut Stevans PCA dapat menghindari masalah ketidakpastian faktor atau komponen yang terbentuk yang biasa ditemukan dalam analisis faktor lainnya (Harrington, 2009).

Metode PCA ini dapat mengumpulkan item-item awal menjadi suatu komponen baru dengan menganalisis semua varians pada observed variabels dan membentuk komponen baru hasil reduksi variabel. Komponen baru hasil analisis PCA menjadi komponen yang lebih kecil dan spesifik serta tidak saling berkorelasi. Hal itu berarti komponen-komponen baru hasil analisis PCA merupakan komponen yang berdiri sendiri dan saling bebas.

Menggunakan principal component analysis (PCA) sebagai analisis properti psikometris akan memberikan item terbaik dalam penyusunan alat ukur final. Item tersebut menggambarkan hal yang 
Jurnal Psikologi Terapan dan Pendidikan

ISSN: 2715-2456

Vol. 1, No. 2, November 2019, pp. 143-181

sebenarnya dalam alat ukur. Dikarenakan analisis komponen ini akan mengumpulkan item-item serumpun berkumpul pada satu komponen tertentu, sehingga ini akan mempermudah peneliti dalam melakukan penyusunan alat ukur final.

Berdasarkan analisis rotasi orthoghonal dan ekstraksi varimaks dari delapan komponen yang dirumuskan menghasilkan item-item yang mengelompok pada tiga komponen utama baru. Setiap komponen baru yang terbentuk merupakan gabungan dari beberapa observed variable yang memiliki korelasi dengan komponen pembentuknya. Komponen baru yang terbentuk melalui hasil analisis PCA menghasilkan jumlah komponen yang sedikit namun mencakup seluruh informasi yang berkaitan dengan komponen berdasarkan observed variables yang melandasinya. Analisis ini menghilangkan korelasi antar komponen yang terbentuk sehingga masing-masing komponen tersebut saling berdiri sendiri dan tidak saling mempengaruhi.

Komponen utama yang pertama terdiri dari item-item daya juang, tahan banting, dan tangguh sebagai observed variables mayor serta kreatif, profesional, dan keberanian sebagai observed variables minor. Komponen utama kedua terbentuk dari item-item kerja keras dan daya juang sebagai observed variables mayor dan item profesional, tangguh, serta tahan banting sebagai observed variables minor. Komponen utama ketiga terdiri dari item-item belajar sepanjang hayat sebagai observed variables yang mendominasi komponen.

Pengelompokan tersebut terjadi karena beberapa faktor seperti item-item yang dibuat pada observed variables tertentu memiliki kemiripan dengan observed variables atau memiliki keterkaitan antara satu dan lainnya sehingga tidak terdapat perbedaan yang signifikan antar komponen tersebut sehingga item-item dari berbagai observed variables tersebut mengelompok membentuk satu komponen utama yang baru. Faktor lain yang menyebabkan mengumpulnya item-item pada satu komponen adalah bahwa beberapa observed variables berasal dari satu komponen utama yang sama sehingga peneliti dapat memberikan satu pengertian atau definisi baru mengenai komponen tersebut. Terlebih sub nilai sebagai indikator yang mendasari nilai karakter utama pada PPK terdapat tumpang tindih antara satu sub nilai dengan sub nilai lain, baik yang terdapat pada satu nilai karakter maupun nilai karakter yang lainnya.

Dengan melakukan analisis faktorial menggunakan teknik Principal Component Analysis (PCA) ini, maka komponen final yang dihasilkan adalah komponen yang telah direduksi berdasarkan kesamaan karakteristiknya menjadi komponen utama yang signifikan sebagai penyusun konstruk serta antar komponen tidak saling berhubungan lagi melainkan berdiri sendiri (independen). Oleh karena itu peneliti harus memberikan label dan definisi baru terhadap komponen baru tersebut, dimana komponen pertama peneliti definisikan sebagai komponen ketekunan, komponen kedua sebagai komponen kegigihan, dan 
yang terakhit komponen ketiga sebagai komponen gemar belajar. Analisis faktorial dengan teknik PCA ini dilakukan menggunakan aplikasi statistic JASP 0.9.0.0. item hasil analisis PCA tersebut digambarkan dalam tabel 1 berikut.

Tabel 1.

Item Hasil Analisis PCA

\begin{tabular}{cccc}
\hline & Ketekunan & Kegigihan & Gemar Belajar \\
\hline Item & $64,67,71,76,77,79,80,83$ & $61,68,72,78,81$ & $73,74,75$ \\
\hline
\end{tabular}

Dalam penyusunan skala final, dari 24 item awal yang telah dibuat direduksi menjadi 16 item. Item ini didapat dari item yang lolos melalui analisis faktorial dengan nilai koefisien muatan faktor dimulai dari 0.447 sampai dengan 0.779 yang berarti item memiliki hubungan yang cukup hingga sangat tinggi sebagai observed variables yang mendasari komponen utama. Hal itu berarti item skala karakter mandirimemiliki kemampuan yang tinggi untuk mengukur karakter-karakter yang mendasari mandiri siswa SMA.

Tabel 2.

Component Loading Hasil Analisis PCA Skala Karakter Mandiri

\begin{tabular}{|c|c|c|c|c|c|}
\hline \multirow{2}{*}{ Item } & \multirow{2}{*}{ Pernyataan } & \multicolumn{3}{|c|}{ Component Loading } & \multirow{2}{*}{ Uniqueness } \\
\hline & & $\mathbf{I}$ & II & III & \\
\hline 64 & Ketika sedang belajar... & 0.447 & & & 0.683 \\
\hline 67 & Saya terbiasa membuat pekerjaan... & 0.644 & $\cdot$ & . & 0.579 \\
\hline 71 & Saya menghargai pendapat... & 0.532 & . & . & 0.647 \\
\hline 76 & Saya siap sedia diberikan... & 0.635 & . & . & 0.567 \\
\hline 77 & Saya cenderung penasaran... & 0.479 & . & . & 0.666 \\
\hline 79 & Ketika diberikan tugas sulit... & 0.652 & . & . & 0.473 \\
\hline 80 & Saya tetap akan menyelesaikan.. & 0.646 & . & . & 0.555 \\
\hline 83 & Lebih baik menahan selera... & 0.466 & 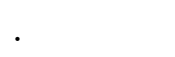 & . & 0.746 \\
\hline 61 & $\begin{array}{l}\text { Saya akan meninggalkan tugas- } \\
\text { tugas... }\end{array}$ & & 0.554 & & 0.670 \\
\hline 63 & Saya berupaya bertanya kepada... & . & 0.453 & . & 0.693 \\
\hline 68 & Saya senang ketika tugas... & . & 0.519 & . & 0.714 \\
\hline 72 & Saya cenderung meminta keinginan... & . & 0.547 & . & 0.678 \\
\hline 78 & Biasanya saya akan mengatakan... & . & 0.480 & . & 0.751 \\
\hline 81 & Saya akan meninggalkan tugas... & 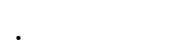 & 0.550 & . & 0.615 \\
\hline 73 & Saya penasaran terhadap trend... & . & . & 0.771 & 0.360 \\
\hline 74 & Saya bertanya-tanya pada... & . & $\cdot$ & 0.779 & 0.365 \\
\hline 75 & Saya cenderung masa bodoh... & . & . & 0.563 & 0.607 \\
\hline
\end{tabular}




\section{Analisis Properti Psikometris}

Validitas Konstrak

Untuk melengkapi analisis properti psikometris skala karakter mandiri pada remaja SMA ini, peneliti melakukan uji validitas konstrak. Menurut Azwar pengujian terhadap validitas konstrak ini dilakukan untuk mengetahui sejauh mana alat ukur mampu mengukur konstrak teoretik yang akan diukur (Periantalo, 2015). Uji validitas konstrak ini dilakukan setelah melakukan uji validitas isi.Uji validitas konstrak yang dilakukan adalah dengan melakukan korelasi antar komponen dalam skala.

Komponen pembentuk skala idealnya akan saling mendukung karena mengungkap hal yang sama dalam alat ukur, namun komponen tersebut bisa saja tidak saling mendukung satu sama lain. Hal tersebut dimungkinkan jika teori atau dasar logika mengatakan bahwa komponen tersebut memang mengungkap hal yang sama, berbeda, atau berlawanan (Periantalo, 2015).

Pada dasarnya ada tiga kemungkinan hasil korelasi antar komponen dalam suatu alat ukur, yaitu mendukung, berbeda, atau berlawanan. Komponen yang saling mendukung akan menunjukkan korelasi positif satu sama lain dan besaran nilai pada suatu komponen akan menunjukan besaran pada nilai komponen yang lain, hasil ini menunjukan validitas konvergen. Disisi lain dapat pula terjadi korelasi antar komponen yang saling berbeda atau tidak berhubungan satu sama lain. Jika dikorelasikan maka akan menghasilkan korelasi yang rendah, korelasi seperti ini merupakan hasil dari validitas diskriminan. Pada validitas diskriminan menunjukkan jika tinggi rendahnya suatu komponen tidak ditentukan dengan komponen lainnya, artinya jika individu mendapat skor tinggi pada satu komponen, maka tidak akan ada kaitan atau hubungannya pada komponen yang lain (Periantalo, 2015).

Hal tersebut seperti hasil analisis faktorial dengan metode principal component analisys yang menghasilkan korelasi komponen yang tidak saling berkaitan melainkan berdiri sendiri (saling bebas). Hasil uji validitas konstrak dengan mengkorelasikan komponen pembentuk skala berdasarkan analisis faktor didapat pada table 3 sebagai berikut.

Tabel 3.

Validitas Konstruk

\begin{tabular}{lrrr}
\hline & Ketekunan & Kegigihan & Gemar Belajar \\
\hline Ketekunan & 1.000 &. &. \\
Kegigihan & -0.000 & 1.000 &. \\
Gemar Belajar & 0.000 & -0.000 & 1.000 \\
\hline
\end{tabular}


Jurnal Psikologi Terapan dan Pendidikan

ISSN: $2715-2456$

Vol. 1, No. 2, November 2019, pp. 143-181

Hasil analisis korelasi komponen tersebut menunjukan bahwa hubungan antara komponen pembentuk skala karakter nasionalisme memiliki korelasi positif dan negatif antar beberapa komponen. Berdasarkan hasil analisis korelasi antar komponen pembentuk konstrak skala diketahui jika komponen ketekunan memiliki hubungan korelasi yang positif dengan komponen gemar belajar. Disisi lain komponen kegigihan memiliki korelasi negatif dengan komponen ketekunan dan gemar belajar. Antar komponen tersebut memiliki koefisien korelasi sebesar 0.00 yang berarti setiap komponen tidak memiliki makna apapun, sekalipun hasil analisis menunjukkan korelasi yang positif ataupun negatif.Ini dikarenakan analisis data menggunakan analisis PCA, sehingga antar komponen tidak lagi berkorelasi melainkan berdiri sendiri (independen) dan tidak memiliki hubungan dengan komponen pembentuk lainnya. Dengan kata lain jika individu mendapatkan skor tinggi atau rendah pada salah satu komponen, tidak akan mempengaruhi atau berhubungan pada skor komponen lain.

Reliabilitas

Salah satu syarat penting properti psikometris yang baik adalah memiliki validitas dan reliabilitas yang baik. Alat ukur dikatakan reliable apabila skala memberikan konsistensi atau keakuratan terhadap hasil pengukuran. Reliabilitas juga mengacu pada seberapa jauh skala tersebut dapat dipercaya untuk mengukur konstruk yang diukur.

Tabel 4.

Reliabilitas

\begin{tabular}{cccc}
\hline & Cronbach's $\boldsymbol{\alpha}$ & Gutmann's $\boldsymbol{\lambda \boldsymbol { 6 }}$ & McDonald's $\boldsymbol{\omega}$ \\
\hline Koefisien & 0.785 & 0.820 & 0.799 \\
$\mathbf{N}$ & 337 & 337 & 337 \\
\hline
\end{tabular}

Berdasarkan hasil uji reliabilitas dengan teknik analisis reliabilitas Cronbach's $\alpha$, gutmann's $\lambda$, McDonald $\omega$, masing-masing menunjukkan koefisien reliabilitas sebesar 0.785, 0.820, dan 0.799 dengan reliabilitas tertinggi menggunakan metode Gutmann's $\boldsymbol{\lambda}$. Secara umum, reliabilitas yang baik jika memiliki koefisien minimal 0.900 (Azwar, 2017). Namun dalam beberapa hal, seperti yang diungkapkan De Vaus (Anggoro \& Widhiarso, 2010) bahwa reliabilitas memiliki nilai yang memuaskan dengan koefisien 0.70. Sehingga dapat dikatakan dengan koefisien sebesar 0.820 menunjukan jika skala karakter mandirimemiliki tingkat kepercayaan yang tinggi.

\section{Norma dan Interpretasi}

Untuk merubah nilai atau skor hasil respon subjek (kuantitatif) sehingga memiliki makna tertentu (kualitatif) maka diperlukan adanya sistem penormaan yang didasari atas skor populasi teoritis sehingga dapat di interpretasi berdasarkan kelompok populasi. Dengan adanya norma maka peneliti atau pengguna 
Jurnal Psikologi Terapan dan Pendidikan

ISSN: $2715-2456$

Vol. 1, No. 2, November 2019, pp. 143-181

skala dapat memaknai respon subjek terhadap hasil pengukuran (Azwar, 2017). Norma dalam penelitian ini menggunakan norma hipotetik untuk menginterpretasi skor alat ukur keseluruhan maupun norma interpretasi komponen.

Norma Alat Ukur Karakter Mandiri

Karakter kemandirian dalam skala ini didefinisikan sebagai suatu kemampuan pada siswa untuk dapat mengatur, mengelola dan mengontrol kehidupannya sendiri yang dicerminkan melalui perilaku yang tidak bergantung pada penilaian dan bantuan orang lain melainkan dengan senang hati mengerahkan segala kemampuan baik pikiran, waktu,energi, dan materi secara maksimal untuk mengerjakan ataupun menyelesaikan tugas, pekerjaan, serta kewajiban demi tercapainya tujuan atau hasil yang diinginkan termasuk didalamnya menikmati setiap proses yang dilakukan oleh diri sendiri dalam kesediaan untuk bertanggung jawab atas tindakan yang diambil. Definisi tersebut memberikan beberapa makna yang mengindikasikan atau yang menjadi karakteristik kemandirian pada individu, yaitu berarti: individu mengandalkan kemampuan dan penilaian sendiri dalam mengatur, mengelola, serta mengontrol diri dan kehidupannya; individu memiliki kapasitas yang memadai untuk memenuhi atau mencapai hasil yang ia inginkan; individu menikmati setiap proses kehidupan yang ia jalankan; juga individu mampu bertanggung jawab atas segala tindakan yang telah ia lakukan.

Makna mengandalkan kemampuannya sendiri dalam mengatur, mengelola, dan mengontrol diri sendiri dan kehidupan menunjukkan suatu kapasitas otonomi yang dimiliki individu. Otonomi merupakan aktualisasi kemandirian individu. Otonomi berarti individu memiliki kekuatan dan kekuasaan untuk mengatur dirinya sendiri - maksudnya adalah individu memiliki kebebasan dalam mengarahkan dirinya pada tujuan atau kehidupan yang ia inginkan. Ini berarti individu memiliki hak dan kebebasan dalam memutuskan apa yang ia inginkan dan lakukan dalam hidupnya, termasuk dalam menentukan tujuan hidup yang menjadi orientasi dari segala perilakunya. Konsep tersebut sejalan dengan gambaran kemandirian yang disebutkan oleh Stott (1938) dimana individu yang mandiri bergantung pada keputusannya sendiri. Ia percaya dan bersedia untuk bertindak berdasakan penilaiannya sendiri dan memikul tanggung jawab atas konsekuensinya.

Individu mandiri yang otonom menggantungkan segala pilihan di hidupnya atas keputusannya sendiri yang mana ini akan mempengaruhi segala sikap dan tindakan yang ia lakukan. Individu yang mandiri berani mengambil keputusan yang baik untuk dirinya - ia mampu memilih hal-hal yang harus ia lakukan dan menolak atau melawan segala hal yang dapat memberikan dampak negatif bagi dirinya. Disisi lain individu yang otonom mengetahui apa yang ia inginkan, sehingga ia akan mengarahkan segala tindakannya untuk mendapatkannya. Individu otonom juga memiliki sistem nilai yang mendasari segala 
Jurnal Psikologi Terapan dan Pendidikan

ISSN: $2715-2456$

Vol. 1, No. 2, November 2019, pp. 143-181

perilaku yang ia lakukan sehingga ia tidak mudah dipengaruhi oleh nilai-nilai yang dimiliki oleh orang lain - namun perbedaan tersebut juga bukanlah hal yang membuat individu otonom menjadi diskriminan atau egois terhadap orang lain, melainkan ia akan menghargai perbedaan nilai tersebut, hanya saja ia tidak akan membiarkan penilaian orang mempengaruhi nilai dan kehidupannya.

Individu yang mandiri dan otonom tidak membiarkan orang lain mengatur atau mengambil kendali atas dirinya - ia tidak membiarkan dirinya berada dibawah tekanan atau paksaan dalam melakukan sesuatu. Meski demikian individu mandiri yang otonom tidak berarti mengabaikan peran orang lain dalam hidupnya, ia tetap bersedia mendengarkan pendapat dan pandangan orang lain, ia memilah pendapat, penilaian, dan saran tersebut - jika itu memberikan hasil yang baik, sesuai dengan sistem nilainya dan dapat membuatnya senang, maka bukan tidak mungkin ia akan mengikuti pendapat atau nilai tersebut. Individu hanya tidak ingin melakukan apa yang diinginkan orang lain atas dirinya terlebih jika itu bukanlah hal yang baik untuk dilakukan dan tidak memberikan kesenangan terhadapnya, melainkan membuatnya tertekan, ataupun terpaksa.

Disamping itu kemandirian individu bukan berarti ia tidak membutuhkan orang lain sama sekali, melainkan ia berupaya sendiri terlebih dahulu dengan kemampuan dan sumber daya yang ia miliki sebelum melibatkan individu lain dalam upayanya. Dengan kata lain individu yang mandiri memiliki kemampuan dan keyakinan atas kemampuannya dalam melakukan sesuatu. Meski demikian apabila diperlukan ia bersedia melibatkan dan menerima bantuan dari orang lain dan hanya dalam kapasitas yang dibutuhkan - bukan menggantungkan tanggung jawab ataupun memanfaatkan orang lain atas tanggung jawab pribadi. Hal tersebut seperti yang diungkapkan oleh Stott (1983) bahwa individu mandiri jarang meminta atau menerima bantuan dari orang lain kecuali ketika diyakinkan oleh kegagalan sebelumnya bahwa ia membutuhkannya.

Individu yang mandiri mampu memutuskan apa yang baik dan tidak baik bagi dirinya - ia berani menolak jika tidak ingin melakukan sesuatu namun ia juga sanggup menerima dan menjalankan penuh tanggung jawab atas apa yang ia pilih. Ia tidak mudah ragu terhadap pilihan-pilihan yang ada karena ia tahu apa yang baik dan tidak baik bagi dirinya - ia tahu apa yang ia inginkan dan tidak inginkan. Hal tersebut menunjukkan kekuatan dan kekuasaan individu sebagai pribadi yang mampu mengatur dan mengelola hidupnyayang menjadikannya sebagai individu yang mandiri.

Disisi lain individu mandiri memiliki kapasitas yang memadai untuk memenuhi atau mencapai hasil yang ia inginkan. Kapasitas yang memadai ini mencerminkan kemampuan kognitif dan afeksi serta sumber daya yang dimiliki yang merujuk pada kemampuan berpikir, energi, waktu, dan materi. Kemampuan berpikir ini mengindikasikan kemampuan kognitif individu untuk dapat berpikir kritis, 
Jurnal Psikologi Terapan dan Pendidikan

ISSN: $2715-2456$

Vol. 1, No. 2, November 2019, pp. 143-181

analisis, dan kreatif dalam membuat perencanaan mencapai tujuan atau hasil yang diinginkan. Kemampuan ini akan membantu individu mengatasi setiap masalah dan hambatan yang ia temui dalam upayanya mencapai tujuan atau hasil yang ia inginkan. Dalam upaya menyelesaikan suatu tugas, pekerjaan, kewajiban ataupun berupaya mencapai suatu tujuan yang diinginkan bukanlah hal mudah. Ada banyak kesulitan yang muncul baik dari dalam diri sendiri ataupun dari luar, namun dengan kemampuan berpikir kritis, analitis dan kreativitasnya ia mampu memikirkan rencana yang baik yang dapat dilakukan untuk mengatasi setiap kesulitan atau hambatan yang muncul sehingga dapat merubah keadaan menjadi lebih baik dan mendapatkan hasil yang maksimal yang mungkin saja melampaui batas yang diperkirakan sebelumnya. Kemampuan ini merujuk pada ketekunan - yaitu kemampuan individu untuk dapat tekun terhadap apa yang ia lakukan.

Selain itu kapasitas energi yang dimiliki individu merujuk pada stamina dan konsistensi tenaga yang dapat dikerahkan individu dalam upayanya menyelesaikan tugas, pekerjaan dan kewajiban atau mencapai tujuannya. Kapasitas energi merujuk pada kerja keras yang mampu dilakukan individu dalam setiap usahanya mencapai dan menyelesaikan sesuatu. Ini merujuk pada kesediaan atau kemauan untuk menyelesaikan suatu tugas - yang mana ini berarti menjaga tujuannya. Kesediaan untuk menyelesaikan tugas dan mencapai tujuan menjadi suatu komitmen yang berarti "tanggung jawab" yang mendorong individu untuk mengerjakannya secara nyata dan bukan lagi sekedar keinginan sampai tujuan tersebut tercapai. Kapasitas ini merujuk pada kegigihan individu.

Kerja keras individu ditambah keseriusan dan kesungguhan hati menyelesaikan tugas ataupun mencapai tujuan akan memberikan hasil yang memuaskan bahkan mungkin melampaui ekspektasi individu. Ini merupakan suatu bentuk kolaborasi antara ketekunan dan kegigihan yang dimiliki individu antara kemampuan kognitif dan afektif individu. Untuk mempertahankan kerja keras atau kegigihan ini, sangat dipengaruhi pula oleh kondisi afeksi seseorang. Bagaimana perasaan, sikap dan nilai yang dimiliki individu terhadap tugas, pekerjaan, kewajiban ataupun tujuannya akan memberikan suatu kecenderungan afek positif dan negatif. Jika itu berupa afek yang positif maka akan memberikan semangat dan kekuatan sehingga memberikan energi yang besar dan kemampuan untuk bertahan hingga tujuannya tercapai atau tugasnya terselesaikan, sebaliknya jika individu memiliki afeksi negatif maka ia akan mudah menyerah, berusaha setengah-tengah atau tidak memberikan usaha yang maksimal, dan bahkan mungkin ia menjadi putus asa sehingga kegagalan pun tidak dapat dihindari.

Telah disebutkan dalam penjelasan sebelumnya jika kemandirian berarti bergantung pada sumber daya sendiri dalam menjalankan kehidupannya. Ini merujuk pada waktu dan materi yang individu miliki dalam meraih dan melakukan apa yang ia inginkan. Dalam upaya mencapai tujuan dan hasil yang 
Jurnal Psikologi Terapan dan Pendidikan

ISSN: $2715-2456$

Vol. 1, No. 2, November 2019, pp. 143-181

diinginkan terkadang tidak dapat diperkirakan durasi waktu yang harus ditempuh individu. Ini bergantung pada kemampuan yang dimiliki individu, kesulitan yang dihadapi dan seberapa besar tujuan dan hasil yang ingin dicapai. Begitu pula dengan materi yang akan dihabiskan-sehingga ini mengindikasikan pada suatu bentuk pengorbanan individu untuk mencapai tujuannya.

Kegigihan dan ketekunan serta pengorbanan sumber daya yang dimiliki yang mengindikasikan karakter kemandirian menjelaskan jika kemandirian bukanlah sekedar kemampuan untuk dapat melakukan segalanya sendiri. Berdasarkan hasil penelitian yang dilakukan menunjukkan jika kemandirian memiliki implikasi lain yaitu memiliki kegigihan yang berarti individu mampu bekerja keras menyelesaikan tugas atau mencapai tujuan serta tekun yang berarti mampu mengatasi kesulitan, masalah, tantangan, ataupun hambatan termasuk dengan mendedikasikan waktu dan materi yang dimiliki hingga dapat memberikan hasil yang memuaskan dan bahkan melebihi target yang diekspektasikan.

Keseluruhan kapasitas kemampuan yang dimiliki individu ini menjadikannya selalu mampu dan siap atas apa yang akan ia lakukan. Individu dapat segera beradaptasi dan menyesuaikan diri terhadap keadaan serta atas inisiatifnya sendiri segera memikirkan berbagai usaha yang dapat dilakukan untuk mengatasi atau memperbaiki keadaan sulit dan tidak menguntungkan sampai menjadi lebih baik serta mencapai hasil yang maksimal. Oleh karena itu individu mandiri yang mampu menggunakan kemampuannya secara optimal dan maksimal tidak akan mudah digagalkan karena ia mampu membuat penyesuaian dan membuat perbaikan terhadap situasi-situasi sulit yang ia hadapi.

Kemandirian juga berarti menikmati setiap proses kehidupan yang ia jalankan. Ini merujuk kepada kemampuan individu untuk menikmati setiap proses yang ia lakukan sehingga ia berlaku jujur dalam sikap dan tindakan dalam menjalankan aktivitas atau usaha mencapai suatu tujuan. Ini merupakan konsekuensi atas otonomi yang dimiliki individu dalam hidupnya. Individu mandiri yang memiliki otonomi terhadap dirinya ia tidak bergantung pada orang lain, yang mana ini memberikan kekuasaan penuh pada dirinya untuk menentukan apa yang diinginkan dan tidak diinginkan serta bagaimana melakukannya. Mereka terbebas dari perasaan tertekan, terpaksa, atau takut atas kuasa orang lain terhadap dirinya. Ia memberikan batasan peran atau kendali orang lain terhadap dirinya, sehingga ia tidak kehilangan kendalinya sebagai individu yang mandiri. Karena menjalankan kehidupan yang ia inginkan ini akan membuat individu menikmati setiap proses kehidupan yang ia jalankan setiap harinya sehingga ia akan melakukan segala sesuatu dengan sepenuh hati.

Konsekuensi lain dari karakter kemandirian siswa SMA berdasarkan hasil penelitian memiliki aspek gemar belajar. Gemar belajar merujuk pada kesediaan dan ketertarikan individu terhadap berbagai hal disekitarnya yang membuat dirinya berupaya untuk mengetahui dan mempelajarinya. Hal tersebut 
Jurnal Psikologi Terapan dan Pendidikan

ISSN: $2715-2456$

Vol. 1, No. 2, November 2019, pp. 143-181

mengindikasikan adanya perasaan positif individu yang senantiasa berusaha untuk selalu terinformasi dengan berbagai hal yang terjadi disekitarnya. Ini dikarenakan untuk menjalankan kehidupan yang selalu berubah dibutuhkan pengetahuan dan keterampilan agar dapat menyesuaikan diri dan mengikuti perubahan kehidupan. Disisi lain, bertambahnya pengetahuan dan keterampilan individu akan dapat membantu individu menjadi lebih mandiri. Ini karena individu memiliki kemampuan dan ia yakin terhadap kemampuannya tersebut. Keyakinan terhadap kemampuan diri adalah kunci individu dalam menjalankan hidupnya dengan mandiri. Disamping itu dalam penelitian ini, gemar belajar memiliki nilai koefisien muatan faktor yang tinggi-ini menunjukan gemar belajar merupakan aspek yang mencerminkan karakter kemandirian pada siswa SMA.

Terlebih gemar belajar tidak hanya sekedar mengetahui dan mempelajari pengetahuan atau keterampilan absolut saja-namun lebih dari itu ini merujuk kepada kemampuan individu untuk dapat memahami bagaimana kehidupan berjalan dan apa saja yang terdapat dalam kehidupan, sehingga individu perlu memahami nilai-nilai penting kehidupan yang ada didalamnya. Ini seperti nilai-nilai kebajikan kemanusiaan, keadilan, dan spiritualitas. Yang mana hal tersebut mungkin tidak terdapat dalam pelajaran konkrit manapun atau tidak cukup dipelajari melalui konsep teoritis, namun harus dipelajari dan dipahami melalui praktik pengalaman individu langsung dalam menjalankan kehidupan.

Meski demikian, otonomi yang memberikan kebebasan pilihan pada individu tidak serta merta membuat individu bebas melakukan apa yang ia inginkan. Terlebih mandiri merupakan salah satu karakter utama kebajikan. Memiliki kebebasan berarti memiliki konsekuensi lain, yaitu bertanggung jawab. Karakteristik lain yang mengindikasikan karakter kemandirian adalah individu mampu bertanggung jawab atas segala tindakan yang ia lakukan dan pilihan yang ia ambil. Seperti yang disebutkan oleh Stott (1983) bahwa individu yang mandiri dan bergantung pada keputusannya sendiri percaya dan bersedia untuk bertindak berdasarkan penilaiannya sendiri dan memikul tanggung jawab atas konsekuensi yang dihasilkan.

Seperti yang disebutkan sebelumnya bahwa kebebasan yang dimiliki individu menunjukkan suatu otonomi individu terhadap diri dan kehidupannya. Meski demikian kebebasan yang dimiliki individu tetaplah harus dipertanggungjawabkan-sejalan dengan pendapat Allmark (2008) yang menyebutkan jika otonomi yang dimiliki individu mensyaratkannya untuk bertanggung jawab secara moral atas suatu tindakannya sebagai individu otonom. Allmark menambahkan ketika individu bertindak secara otonom, besar kemungkinan juga bahwa ini akan menjadi kondisi yang cukup untuk membuatnya bertanggung jawab secara moral. Maka dari itu individu perlu berpikir secara rasional sebelum mengambil tindakan, memikirkan dan mempertimbangkan berbagai konsekuensi yang muncul dalam setiap tindakan yang akan 
Jurnal Psikologi Terapan dan Pendidikan

ISSN: 2715-2456

Vol. 1, No. 2, November 2019, pp. 143-181

ia ambil. Tindakan mandiri dan bertanggung jawab ini merujuk pula pada perilaku yang berorientasi pada kejujuran dan kebenaran seperti tidak berbuat curang, menipu, ataupun menyakiti orang lain.

Kemandirian dan segala aspeknya berkembang bahkan sejak masa balita hingga ia tumbuh semakin dewasa. Berdasarkan tahap perkemabangan psikososial Erikson (Santrock, 2009) sejatinya telah dimulai sejak usia 1 sampai 3 tahun. Pada usia ini balita harus menyadari perilakunya sebagai milik mereka sendiri - mereka mulai menyatakan rasa kemandirian atau otonominya. Pada tahapan usia selanjutnya yaitu kanak-kanak pra sekolah, individu sudah harus mengembangkan kemampuan prakarsa atau inisiatifnya. Anak-anak diharapkan bertanggung jawab terhadap perilaku, tubuh, maupun mainannya. Individu pada usia tersebut harus mengembangkan kemampuan untuk bertanggung jawab.

Memasuki tahapan masa kanak-kanak yang mulai bersekolah, individu harus mengembangkan kemampuan tekun pada dirinya. Sebagai implikasi berkembangnya kemampuan prakarsa pada anak memasuki masa sekolah dasar kemampuan prakarsa tersebut mendorong anak terlibat dalam pengalamanpengalaman baru yang lebih kaya. Pada masa ini anak belajar mengarahkan energinya untuk menguasai pengetahuan dan keterampilan intelektual. Masa ini merupakan masa dimana anak lebih bersemangat dan antusias untuk belajar sehingga mejadi dasar dan tolak ukur untuk mengembangkan kepercayaan diri pada anak akan kemampuannya. Kegagalan anak belajar pada masa ini akan membuat anak mengembangkan rasa tidak kompeten dan tidak produktif sehingga anak memiliki rasa rendah diri yang akan mengganggu perkembangan lain individu. Tahap selanjutnya adalah masa remaja dimana individu harus mengembangkan identitas dirinya. Pada masa ini individu harus membentuk identitas dirinya sendiri. Ketidakmampuan individu untuk memiliki otonomi terhadap dirinya, kegagalan individu untuk menghasilkan sesuatu dan tidak dapat bertanggung jawab atas apa yang ia miliki dan lakukan dengan benar membuat individu mengembangkan rasa rendah diri yang berdampak pada individu mengembangkan rasa inferior terhadap dirinya. Sebaliknya, jika individu mampu mengambil tanggung jawab atas dirinya, mampu melakukan sesuatu dengan baik ini akan menghasilkan konsep diri yang baik karena individu percaya akan kemampuannya dalam melakukan sesuatu (Santrock, 2009). Hal itu akan membantu individu dalam memenuhi tugas perkembangannya sebagai remaja (Hurlock, 2014). Hal itu akan memperkuat karakter kemandirian pada diri individu seiring perkembangannya menjadi pribadi dewasa.

Disisi lain kemandirian bergantung pada kontrol diri yang dimiliki individu. Telah disebutkan bahwa kemandirian memberikan kekuasaan kepada individu untuk mengatur, mengelola dan mengontrol diri dan hidupnya. Ini menegaskan jika kontrol diri adalah bagian dari kemandirian individu. Seperti di didefinisikan Chaplin (2006) bahwa kontrol diri merupakan kemampuan untuk membimbing tingkah laku 
sendiri dalam menekan dan merintangi impuls atau tingkah laku yang bersifat impulsif. Kontrol diri ini menjadi filter individu dalam mengontrol perilakunya - apa yang harus dan tidak harus dilakukan terhadap diri, kehidupannya dan orang-orang disekitarnya. Individu yang memiliki kontrol diri yang baik akan mengikuti dan taat terhadap komitmen moral dan mempertanggungjawabkan pilihan yang telah ia pilih. Oleh karena itu untuk memiliki kontrol diri yang baik yang mengatur perilakunya, individu membutuhkan pula seperangkat sistem nilai moral yang baik yang menjadi penguat yang melandasi kontrol dirinya.

Tabel 5 dibawah ini adalah tabel kategorisasi norma hipotetik alat ukur karakter Mandiri secara keseluruhan yang mengklasifikasikan respon subjek terhadap item. Terbagi menjadi lima jenjang kontinum nilai yaitu; sangat tidak mandiri, tidak mandiri, cukup mandiri, mandiri, sangat mandiri.

Tabel 5.

Norma Hipotetik Skala Karakter Mandiri

\begin{tabular}{lc}
\hline \multicolumn{1}{c}{ Klasifikasi } & Skor \\
\hline Sangat mandiri & $\geq 56$ \\
Mandiri & $\geq 48-55$ \\
Cukup mandiri & $\geq 32-47$ \\
Tidak mandiri & $\geq 24-31$ \\
Sangat tidak mandiri & $<24$ \\
\hline
\end{tabular}

\section{Norma Skala per Komponen}

Untuk dapat mengelompokan dan menjelaskan bagaimana dinamika karakter mandiri pada diri individu, maka peneliti membuat kategorisasi norma berdasarkan komponen yang membentuk konstruk skala karakter mandiri. Sehingga dapat diketahui dengan jelas dinamika karakter mandiri pada diri individu pengguna alat ukur skala karakter mandiri ini.

Kategori Norma Hipotetik Komponen Ketekunan

Komponen ketekunan yang menyusun skala karakter mandiri ini didefinisikan sebagai perilaku yang menunjukkan sikap dan tindakan siswa yang mencerminkan kemampuan untuk dapatmengerjakan tugas, pekerjaan, atau kewajiban dengan mengerahkan segala potensi yang dimiliki agar dapat menyelesaikan tugas, pekerjaan, atau kewajiban tersebut termasuk kemampuan mengatasi permasalahan ataupun kesulitan internal maupun eksternal hingga memberikan hasil atau mendatangkan keadaan yang memuaskan atau bahkan lebih baik dari sebelumnya. Pengertian tersebut mengindikasikan beberapa 
Jurnal Psikologi Terapan dan Pendidikan

ISSN: $2715-2456$

Vol. 1, No. 2, November 2019, pp. 143-181

makna sekaligus, yaitu adanya kemampuan individu untuk berjuang merubah keadaan atau mendapatkan hasil yang lebih baik dengan tekad mengatasi permasalahan tersebut; menunjukkan suatu upaya untuk mengerahkan seluruh usaha mengatasi permasalahan mencapai hasil yang lebih baik dan memuaskan dengan kemampuan kognitif dan afeksi yang dimiliki; juga kemampuan untuk dapat bertahan dalam segala situasi sulit lainnya yang muncul dan membutuhkan strategi baru dan berbeda dari sebelumnya untuk mengatasi permasalahan.

Definisi ketekunan tersebut sebagai salah satu aspek penting yang membentuk karakter kemandirian didasarkan pada kumpulan item-item sebagai observed variables yang membentuk komponen ini. Komponen ketekunan terdiri dari item daya juang, tangguh, dan tahan banting sebagai observed variables yang mendominasi karakter ini dengan nilai koefisien muatan faktor yang tinggi atau sangat baik, kemudian terdapat item profesional, keberanian, dan kreatif sebagai observed variables yang mendukung aspek ketekunan ini.

Ketekunan dalam hal ini memiliki makna kemampuan untuk bertahan dan berjuang dalam membuat atau mendatangkan keadaan atau hasil yang lebih baik dari berbagai hal atau kemungkinan yang menyulitkan atau tidak menguntungkan. Ini dikarenakan ketekunan berkaitan dengan bagaimana individu mengupayakan kemampuan yang ia miliki yaitu kemampuan kognitif dan kecerdasan emosionalnya untuk mengatasi kesulitan, hambatan, dan bahkan ketidakberdayaan yang datang dengan tekad yang kuat. Tekad yang kuat mengindikasikan adanya ketangguhan dalam diri individu - yang menunjukkan bahwa individu adalah pribadi yang kuat dan pantang untuk menyerah, ia tidak ingin dikasihani ataupun mengeluh dan sebaliknya ia akan berusaha untuk menunjukkan totalitas kemampuan yang ia miliki untuk menghadapi kesulitan atau tantangan seberat dan sebesar apapun itu. Terlebih dengan unsur daya juang yang mendasari aspek ini - menunjukkan jika individu yang tekun adalah ia yang mampu mengarahkan serta merubah segala kesulitan atau kondisi yang tidak menguntungkan dalam menyelesaikan suatu tugas atau melaksanakan kewajiban dan pekerjaan menjadi sesuatu yang menguntungkan dan memberikan hasil yang optimal bahkan mungkin mencapai lebih dari apa yang diharapkan. Ini menjelaskan bahwa individu yang tekun bukanlah individu yang statis, melainkan individu yang dinamis. Individu tidak hanya sekedar berusaha bertahan dalam kesulitan atau situasi tidak menguntungkan, melainkan melakukan aksi sebagai suatu upaya untuk merubah kesulitan atau keadaan yang tidak menguntungkan tersebut menjadi lebih baik - sekalinya satu usaha gagal, ia akan berupaya melakukan usaha lain yang akan mengantarnya pada tujuan atau keadaan yang diinginkan.

Karakteristik daya juang dan ketangguhan ini membuat individu yang tekun tahu apa yang harus ia lakukan atau usahakan untuk merubah keadaan. Individu yang tekun tidak keras kepala untuk 
Jurnal Psikologi Terapan dan Pendidikan

ISSN: $2715-2456$

Vol. 1, No. 2, November 2019, pp. 143-181

melakukan sesuatu yang mungkin saja tidak bekerja sehingga memiliki alternatif rencana lain yang akan ia lakukan - ia bukan tidak tegas melainkan ia tahu kapan harus mengambil tindakan dan merubah tindakan, ia tenang, mantap, dan juga kuat. Ia mampu untuk memperjuangkan dan melakukan apa yang ia rencanakan dengan baik, teliti, dan hati-hati hingga mencapai apa yang ia inginkan atau setidaknya mendekati hasil yang memuaskan atau bahkan mencapai hasil diluar dari yang diinginkansekalipun sebelumnya ia dihadapkan pada situasi yang tidak menguntungkan.Oleh karena itu ketekunan juga dapat digambarkan sebagai upaya untuk merubah hal negatif atau tidak menguntungkan menjadi mendatangkan hal yang positif. Ini menandakan jika ketekunan berarti menyelematkan individu dari ketidak beruntungan, kesulitan, serta hambatan dan tampil lebih baik dari sisi yang lain.

Disisi lain ketekunan yang membentuk karakter siswa SMA ini juga merujuk pada adanya daya tahan atau kemampuan bertahan (tahan banting) yang berarti bagaimana individu mampu untukmelaksanakan atau melanjutkan komitmennya untuk terus berjuang menyelesaikan tugas, pekerjaan, atau kewajiban bahkan sekalipun dihadapkan pada kemungkinan situasi yang tidak menguntungkan (kemungkinan tidak berhasil) - individu yang tekun akan mampu merubah atau mengupayakan ketidak beruntungan itu menjadi sesuatu yang mendatangkan sedikit kebaikan atau keuntungan yang lain.

Selain itu daya tahan sebagai karakteristik individu yang tekun juga mengindikasikan bahwa individu dapat bertahan tidak hanya pada satu situasi sulit atau tidak menguntungkan saja melainkan dalam berbagai situasi yang sulit dengan kesulitan dan tantangan yang berbeda di lain waktu. Ini menandakan adanya konsistensi untuk tetap terus bertahan dan berjuang mengatasi masalah atau kesulitan yang berulang pada situasi yang lain - karena tantangan yang dihadapi individu tidak akan konstan dan sama, melainkan selalu ada tantangan atau masalah yang berbeda yang harus diatasi untuk mencapai tujuan akhir. Individu yang tekun ia akan berupaya untuk mengatasi kesulitan-kesulitan serta masalahmasalah yang datang dalam kehidupannya dalam berbagai bentuk dan macam dengan sungguh-sungguh. Ini sepertipengertian ketekunan dalam Merriam Webster (2019) yang berarti upaya yang dilakukan terus menerus untuk melakukan atau mencapai sesuatu terlepas dari kesulitan, kegagalan, atau pertentangan. Hal tersebut menunjukkan jika ketekunan berarti adanya konsistensi individu dalam berusaha dan berupaya untuk berusaha mendapatkan kebaikan atau keuntungan yang sama dari situasi sulit yang lain.

Konsistensi yang dimaksudkan dalam ketekunaan ini menunjukkan bahwa 'tekun' bukan lah proses yang mudah, sebentar, dan dangkal melainkan akan membutuhkan waktu yang panjang dan usaha yang keras.Ini dikarenakan ketekunan sejatinya perjuangan mendapatkan hasil atau tujuan yang baik dengan mengatasi berbagai kesulitan, tantangan ataupun rintangan yang beraneka ragam - dimana ini tidak akan berlangsung dalam durasi yang pendek atau sebentar, proses yang dibutuhkan berkemungkinan 
Jurnal Psikologi Terapan dan Pendidikan

ISSN: $2715-2456$

Vol. 1, No. 2, November 2019, pp. 143-181

lama bergantung kemampuan individu dan situasi kesulitan tersebut. Ketekunan juga menunjukkan adanya dedikasi individu terhadap tujuan yang ia yakini meskipun tampaknya tidak ada harapan; bahkan ketika mereka dihantam oleh rintangan demi rintangan. Peterson dan Seligman (2003) menyebutkan konsistenensi dalam komponen ketekunan ini sebagai suatu kepercayaan ketekunan dan sikap ketekunan - yang mana kepercayaan dan sikap ini harus dipelihara dalam menghadapi berbagai tantangan dan kesulitan. Oleh karena itu ketekunan tidak pernah ada batasan waktu, individu akan senantiasa bertahan dan berjuang, sehingga secara konsisten ketekunan menjadi suatu kecenderungan karakter dalam dirinya.

Konsistensi ini juga seperti apa yang dikonsepkan oleh Ladd dan Woodworth (Ryans, 1938) yang mengartikan ketekunan sebagai adanya sebuah kecenderungan untuk mengulang suatu tindakan dari waktu ke waktu, terlebih ketika telah dirangsang oleh stimulus yang tepat. Stimulus yang dimaksud oleh Ladd dan Woodworth ini merupakan suatu harapan - bahwa adanya harapan atas apa yang mereka pertahankan dan perjuangkan akan mendatangkan hasil yang mereka inginkan - bahkan ini memungkinkan untuk melebihi dari apa yang mereka harapkan. Hal tersebut seperti yang disebutkan oleh Peterson dan Seligman (2003) bahwa individu yang tekun umumnya mereka mengharapkan apa yang mereka perjuangkan akan dihargai dengan hasil yang mereka inginkan.

Lebih jauh ketekunan juga mengindikasikan adanya ketabahan atau sikap 'tabah' dalam mencapai tujuan atau mendapatkan hasil yang diinginkan - ini dikarenakan individu yang tekun akan terus berjuang, bertahan dan berusaha mengupayakan yang terbaik yang bisa ia lakukan agar dapat terlepas dari kesulitan yang ia hadapi berapa lama pun waktu yang ia butuhkan agar tercapai tujuan yang diinginkan. Dengan ketekunan, individu memelihara ketahanan diri, energi, usaha serta semangatnya karena untuk tekun, individu membutuhkan stamina dan daya tahan untuk terus berusaha. Ini merupakan realisasi dari kombinasi unsur daya juang, tangguh, serta tahan banting yang mendasari ketekunan seseorang.Sebagaimana Duckworth, Peterson, Matthews dan Kelly (2007) mendefinisikan ketabahan sebagai sebuah ketekunan dan gairah untuk tujuan jangka panjang.Lebih lanjut menurut mereka ketabahan mensyaratkan kerja keras untuk menghadapi tantangan, mempertahankan usaha dan minat selama bertahun-tahun untuk terlepas dari kegagalan, kesulitan, dan tebing tinggi yang menghalangi kemajuan individu untuk mencapai tujuannya.

Disisi lain ketekunan juga mensyaratkan adanya kemampuan baik kognitif ataupun emosional untuk dapat mengatasi masalah yang muncul ditengah-tengah usaha mencapai tujuan.Ini mengindikasikan bahwa ketekunan tidak hanya sekedar mendedikasikan tenaga untuk terus berusaha atau melanjutkan komitmen untuk tetap menyelesaikan atau mencapai tertentu saja, melainkan terdapat upaya yang 
Jurnal Psikologi Terapan dan Pendidikan

ISSN: 2715-2456

Vol. 1, No. 2, November 2019, pp. 143-181

melahirkan usaha-usaha untuk mengatasi permasalahan sebagai upaya mencapai hasil atau tujuan yang diinginkan. Untuk dapat menghasilkan usaha yang tepat untuk mencapai hasil atau tujuan dibutuhkan suatu kemampuan berupa kecerdasan kognitif dan emosional - kombinasi antara kecerdasan kognitif dan emosionalakan melahirkan keselarahan antara apa yang direncanakan sehingga dapat membentuk sikap dan menghasilkan tindakan yang sesuai dengan apa yang direncanakan, hal ini semata agar didapatkan hasil atau upaya yang memuaskan dari apa yang diperjuangkan.

Kemampuan kognitif dan emosional yang dimaksud disini bukanlah sebuah kecerdasan intelektual (IQ) dengan tingkat derajat tertentu - melainkan kemampuan berpikir kreatif dan sikap profesional individu. Bukanlah kecerdasan tunggal atau pemikiran yang statis - melainkan kemampuan untuk berpikir dinamis yang dapat mengembangkan ide-ide atau cara baru sebagai upaya untuk memecahkan permasalahan dan menemukan peluang. Individu yang kreatif ia akan memiliki banyak ide yang baru atau modifikasi dari suatu ide atau cara yang telah ada kemudian selanjutnya ia kembangkan atau rubah sesuai situasi yang dibutuhkan saat itu. Kreativitas tidak hanya dimiliki atau terdapat pada individu dengan IQ yang tinggi, kreativitas dimiliki oleh tiap-tiap individu namun dalam taraf kemampuan yang berbeda-beda. Ini bergantung pada bagaimana individu mengasah kemampuan kreatifnya untuk dikembangkan dan ditingkatkan.

Kreatifitas seringkali muncul dalam cara yang tidak logis, namun memiliki arti penting dan dapat digunakan. Individu lain biasanya berpikir secara statis dan lebih memilih sesuatu yang masuk akal (logis) menurut pandangannya sehingga menolak hal-hal yang diluar logika - yang mana merupakan beberapa jalan munculnya kreativitas. Dengan adanya kreatifitas individu akan mampu berpikir rencana atau strategi apa yang digunakan untuk mencapai tujuannya - ia akan mengarahkan kemampuannya tersebut untuk memikirkan berbagai cara yang kreatif untuk mencapainya. Disisi lain saat satu ide atau cara tidak berjalan sesuai harapan, individu tekun yang memiliki kreatifitas yang memadai akan mampu memikirkan ide, cara atau rencana lain untuk mengatasi permasalahannya - ia tidak akan kehabisan ide, melainkan berupaya mengerahkan segala kemampuan kreatifnya untuk menyelesaikan masalahnya dan mencapai tujuannya.

Telah disebutkan sebelumnya bahwa kemampuan dalam ketekunan tidak hanya merujuk pada kemampuan kognitif saja, melainkan turut melibatkan kemampuan atau kecerdasan emosional. Kecerdasan emosional yang dimaksud dalam komponen ini merujuk pada sikap dan tindakan profesionalisme individu. Profesionalisme berarti bagaimana individu membentuk sikapnya agar ia mampu menampilkan keahlian dan pengetahuannya dengan cara yang etis dan bertanggung jawab. Sikap profesionalisme ini akan mendorong individu untuk mengerahkan segala tindakannya agar mengarah 
Jurnal Psikologi Terapan dan Pendidikan

ISSN: $2715-2456$

Vol. 1, No. 2, November 2019, pp. 143-181

kepada tujuan atau hasil sesuai rencana atau strategi yang telah dikembangkan sebelumnya. Profesionalisme ini membantu individu untuk tampil enerjik dan bergairah dengan memelihara staminanya dalam mengejar apa yang ia inginkan.

Kolaborasi antara kemampuan kognitif berupa kreativitas dan kecerdasan emosional berupa sikap profesionalisme sejalan dengan apa yang disebutkan oleh Galton (Duckworth, Peterson, Matthews \& Kelly, 2007) bahwa ia meyakini jika suatu pencapaian didapatkan individu dikarenakan adanya kombinasi dari kemampuan, semangat, dan kapasitas untuk bekerja keras. Disisi lain ketekunan - yang berarti adanya keselarasan antara kecerdasan kognitif dan kecerdasan emosional juga dapat disebut sebagai suatu bakat - suatu istilah yang diperkenalkan oleh Duckworth, Peterson, Matthews dan Kelly (2007) sebagai sinonim dari ketabahan. Hal tersebut dikarenakan tidak setiap individu mampu mengintegrasikan kedua kecerdasan tersebut. Ketekunan tidak hanya berarti kemampuan menemukan cara mengatasi permasalahan saja ataupun komitmen terus bertahan hingga masa sulit terlewati melainkan bagaimana individu mampu mengintegrasikan kedua aspek kecerdasan itu sehingga menghasilkan upaya dan ketahanan yang maksimal agar tercapai tujuan yang diinginkan.

Dalam literatur lain yang dijelaskan oleh Josephson (2002) - menyebutkan jika ketekunan sebagai suatu kesatuan sebagai upaya mengejar keunggulan atau dapat disebut pula prestasi ataupun mencapai tujuan. Individu yang tekun menunjukan kualitas lain dari dirinya berkaitan dengan kemampuan kognitif dan emosional yang ia miliki, dimana tekun yang dimaksud oleh Josephson adalah individu memiliki rasa 'kewajiban' untuk berusaha melakukan sesuatu yang terbaik dengan bersungguh-sungguh, selalu teliti atas apa yang ia lakukan, selalu siap, dan memiliki toleransi yang rendah terhadap kesalahan maksudnya adalah individu yang tekun sangat tidak mentolerir kesalahan atau bahkan menyelesaikan sesuatu dengan penilaian atau kualitas dibawah standar. Individu yang tekun sangat bersungguh-sungguh atas apa yang ia lakukan. Baginya, melakukan suatu kesalahan termasuk sesuatu yang tidak etis dilakukan ataupun terjadi, sehingga ia sangat berhati-hati dalam apapun yang ia lakukan. Definisi tekun dari Josephson tersebut juga menunjukkan karakteristik diri sebagai suatu kualitas lain dari individu tekun. Selain itu, keberhasilan individu untuk mencapai tujuan hasil yang diinginkan dapat diprediksi berdasarkan ketekunan, keyakinan diri, dan integrasi kearah tujuan lain. Hal tersebut merupakan kualitas lain dari aspek nonkognitif yang keberhasilan individu.

Disisi lain ketekunan juga mengindikasikan kualitas lain dari diri individu - yaitu adanya keberanian dalam dirinya untuk terus bertahan dan berjuang memperjuangkan tujuan atau hasil yang ia inginkan. Ini dikarenakan individu yang tekun berusaha memelihara konsistensi daya dan upaya selama proses mencapai tujuan yang dapat berlangsung dalam jangka panjang. Durasi waktu yang terkadang 
Jurnal Psikologi Terapan dan Pendidikan

ISSN: $2715-2456$

Vol. 1, No. 2, November 2019, pp. 143-181

dapat menjadi lama serta membutuhkan berbagai usaha yang mungkin saja mengalami perubahan dikarenakan kegagalan - sehingga perjuangan ini akan menjadi suatu pengorbanan tersendiri bagi orang yang tekun. Ini semata untuk mencapai hasil atau tujuan yang memuaskan - suatu bentuk dedikasi individu terhadap tujuan yang ingin dicapai. Hal ini juga dikarenakan individu yang tekun, ia tahu apa yang ia perjuangkan sehingga ia berani untuk mengorbankan waktu, tenaga, dan kemampuannya untuk berusaha mencapai apa yang ia harapkan. Kerelaan untuk berkorban tersebut merupakan suatu bentuk keberanian dari individu yang tekun-ini menunjukkan kualitas dari individu tekun.

Disamping itu dengan melihat keberanian yang dimiliki oleh individu untuk berjuang dan berkorban-mengatasi permasalahan yang muncul agar mencapai kondisi yang lebih baikmengindikasikan adanya kontrol diri yang baik dari diri individu.Ia mampu mengendalikan hasrat ataupun godaan untuk berhenti atau bersikap asal-asalan, pasrah terhadap keadaan atau bentuk godaan lain yang datang dan menyinggung akal sehatnya. Namun telah disebutkan sebelumnya bahwa individu yang tekun, ia tahu apa yang sedang ia perjuangkan - ia tahu apa yang dikorbankan, ini semata agar ia mendapatkan hasil dan tujuan yang memuaskan untuk dirinya. Bahkan individu ini berani menunda kepuasan jika perlu untuk mendapatkan hasil yang memuaskan tersebut. Suatu bentuk keberanian individu yang tekun. Ini merupakan bagian sekaligus nilai yang harus dikembangkan pada diri remaja, ini karena kebanyakan remaja tidak suka dan tidak mampu bertahan dalam proses panjang - mereka lebih mendambakan kepraktiksan dan kehidupan yang serba instan yang mana ini mengindikasikan kualitas buruk dari diri remaja karena tidak memiliki daya juang dan daya tahan untuk berusaha mendapatkan yang ia inginkan. Ini juga lah yang menyebabkan lambatnya kemajuan bangsa dan buruknya kualitas karakter remaja, mereka yang tidak terbiasa berjuang hanya akan sering pasrah dan tidak berorientasi pada prestasi - ketika ingin mendapatkan yang ia inginkan, ia akan menggunakan berbagai cara termasuk dengan cara yang tidak terpuji.

Merujuk pada konsep empiris ketekunan dan pentingnya arti ketekunan bagi pengembangan pribadi dan bangsa, maka dapat disimpulkan bahwa penting bagi remaja SMA untuk memiliki dan mengembangkan ketekunan dalam dirinya. Hal ini dikarenakan ketekunan merupakan esensi dari suatu proses pencapaian prestasi yang tinggi (Duckworth, Peterson, Matthews \& Kelly, 2007). Disisi lain pada masa ini individu remaja sedang berada pada tahapan identitas versus kebingungan identitas menurut tahapan perkembangan psikososial yang diperkenalkan oleh Erikson (Santrock, 2009). Pada masa ini remaja sedang mempersiapkan diri pada peran-peran baru dan status dewasa. Remaja diharapkan dapat mengembangkan kemampuan untuk mengatasi masalah dan berjuang bertahan mengatasi berbagai kesulitan, baik yang berasal dari internal ataupun eksternal seperti lingkungan keluarga, sekolah ataupun 
Jurnal Psikologi Terapan dan Pendidikan

ISSN: $2715-2456$

Vol. 1, No. 2, November 2019, pp. 143-181

lingkungan pertemanan. Remaja dituntut untuk dapat memiliki kematangan emosional dan kecerdasan untuk dapat berjuang dan bertahan mengatasi berbagai permasalahan tersebut. Dengan memiliki ketekunan dalam diri remaja ini akan membantu individu lebih dapat mempercayai kemampuan dirinya, ia memiliki ketahanan diri untuk terus bertahan dan berjuang mendapatkan apa yang ia inginkan dengan kerja kerasnya, lebih daripada itu pada remaja ini akan membuat mereka berorientasi pada tujuan dan prestasi - sehingga mereka akan berusaha keras mencapai apa hasil atau tujuan yang mereka inginkan. Dengan begitu ketekunan akan membantu remaja membentuk konsep dirinya dan membuat mereka lebih percaya terhadap dirinya yang akan membantu mereka dalam menghadapai tugas perkembangan ditahapan selanjutnnya. Sebaliknya jika individu tidak mampu mengembangkan ketekunan dalam dirinya ini mengindikasikan kerentanan untuk individu menghadapi keputusasaan atau ketiadaan tujuan yang ingin ia capai, ini menunjukkan sekaligus mengakibatkan munculnya rasa inferioritas dalam diri remaja tersebut sehingga menghasilkan konsep mengenai diri yang negatif.

Dalam psikologi ketekunan dapat dikaitkan dengan gaya atribusi atau eksplanatori. Menurut Peterson (Liu \& Bates, 2014) gaya atribusi mengacu pada penjelasan yang diberikan individu untuk penyebab peristiwa positif atau negatif dalam hal stabilitas, gobalitas, dan internalitas dikarenakan penjelasan tersebut mempengaruhi perilaku dan suasana hati individu. Lebih lanjut dalam hal ini ketidakmampuan individu mengembangkan ketekunan berkaitan dengan gaya atribusi dari teori ketidakberdayan yang dipelajari. Gaya atribusi menjelaskan fakta bahwa kebiasaan individu untuk dalam menjelaskan peristiwa di sepanjang dimensi internalitas, stabilitas dan globalitas memprediksi bagaimana ia merespon peristiwa negatif (Peterson \& Seligman, 2003). Menurut Peterson dan Park (Peterosn \& Seligman, 2003) Individu yang mengembangkan perasaan ketidakberdayaan yang dipelajari setelah mengalami peristiwa-peristiwa negatif sehingga ia memiliki lebih banyak kesulitan dalam mencapai tujuan mereka dibandingkan individu-individu lainnya yang mengaitkan peristiwa buruk dengan penyebab yang kurang stabil dan global. Individu yang berpikir bahwa hal-hal buruk akan terjadi - tidak peduli apa yang ia lakukan (suatu respons ketidakberdayaan yang dipelajari) tidak mampu untuk mengarahkan kegigihan yang lebih besar bahkan ketekunan sekalipun - padahal disisi lain ketika individu memiliki harapan yang positif ini akan meningkatkan motivasi untuk mencoba dan bertahan. Ini merupakan kualitas diri individu yang tekun, yaitu memiliki sikap optimistik terhadap apa yang akan ia inginkan dan lakukan.

Disisi lain kecenderungan individu mengejar tujuan jangka panjang dengan ketekunan dan semangat juga dapat dikarenakan adanya keyakinan mengenai kemampuan yang dimiliki oleh individu tersebut. Yang mana ini akan membentuk konsep diri yang baik pada diri individu - terlebih remaja. 
Jurnal Psikologi Terapan dan Pendidikan

ISSN: $2715-2456$

Vol. 1, No. 2, November 2019, pp. 143-181

Remaja yang memiliki gaya atribusi ini dan mengembangkan adanya perasaan ketidakberdayaan dalam melakukan sesuatu atau mencapai sesuatu ini lah yang memicu adanya perasaan inferioritas pada remaja dimana jika ini terus berlangsung tanpa berhasil diperbaiki - menyulitkan penyesuaian remaja ditahapan perkembangan selanjutnya yang mana ini akan menghambat kesuksesannya.

Komponen ketekunan yang menyusun karakter mandiri dalam skala ini memiliki standar penilaian dan interpretasi yang dapat dijelaskan dalam table 6 dibawah ini.

Tabel 6.

Norma Hipotetik Komponen Ketekunan

\section{Klasifikasi Skor}

\begin{tabular}{lc}
\hline Sangat tekun & $\geq 28$ \\
Tekun & $\geq 24-27$ \\
Cukup tekun & $\geq 16-23$ \\
Tidak tekun & $\geq 12-15$ \\
Sangat tidak tekun & $<12$ \\
\hline
\end{tabular}

Kategori Norma Hipotetik Komponen Kegigihan

Komponen kegigihan yang menyusun skala karakter mandiri ini didefinisikan sebagai perilaku yang menunjukan kemampuan siswa untuk dapat bertahan dan terus menyelesaikan tugas, pekerjaan atau kewajiban yang diberikan sampai mencapai hasil atau tujuan yang diinginkan. Kegigihan dalam pengertian tersebut memiliki makna kekuatan atau energi untuk memberikan aksi yang konsisten terus menerus hingga mencapai hasil atau tujuan yang diharapkan. Ini dikarenakan kegigihan diartikan sebagai kemampuan individu untuk terus menyelesaikan apa yang telah ia mulai sampai selesai sesuai tujuan dan hasil yang telah ditargetkan bagaimanapun kesulitan dan tantangan yang ia hadapi.

Konstruk mengenai ketekunan dan kegigihan tampak memiliki kesamaan dan keterkaitan namun sebenarnya memiliki konsep yang berbeda. Kesamaan ini dikarenakan kedua aspek tersebut menunjukan adanya tindakan kelanjutan dalam mengerjakan suatu tugas, pekerjaan atau kewajiban. Ketika ketekunan berarti tekad untuk mengatasi kesulitan yang muncul saat menyelesaikan suatu tugas, pekerjaan, dan kewajiban - kegigihan berarti suatu pilihan dan komitmen untuk terus menyelesaikan tugas, pekerjaan, atau kewajiban tersebut sampai selesai.

Saat kegigihan melayani suatu pilihan untuk terus menyelesaikan tugas sampai mencapai hasil yang diinginkan, kemudian individu yang tekun merespon pilihan atau komitmen untuk menyelesaikan 
Jurnal Psikologi Terapan dan Pendidikan

ISSN: $2715-2456$

Vol. 1, No. 2, November 2019, pp. 143-181

tugas dengan mengerahkan segala kemampuan yang dimiliki untuk mengatasi permasalahan dan kesulitan yang ada agar tujuan atau hasil yang diharapkan tercapai dengan hasil yang optimal dan memuaskan. Sementara itu, pilihan atau komitmen untuk terus mengerjakan tugas sampai selesai dapat saja tidak mendapatkan upaya yang besar dan berarti karena individu tersebut tidak mengerahkan segala kemampuannya untuk membuat situasi atau mencapai hasil yang lebih baik dan optimal - merupakan indikasi dari individu yang tidak memiliki ketekunan dalam dirinya. Ini merupakan bentuk kolaborasi dan saling keterkaitan antara ketekunan dan kegigihan. Individu yang tekun ia telah menunjukkan kegigihan dalam dirinya, sementara individu yang gigih belum tentu mengerahkan kemampuannya untuk menjadi tekun.

Komponen kegigihan tersusun dari item-item kerja keras dan daya juang sebagai observed variables utama yang menyusun komponen dengan muatan faktor yang tinggi. Selain itu juga terdapat item profesional, dan tahan banting sebagai observed variables yang melengkapi komponen kegigihan dengan nilai muatan faktor yang cukup. Berdasarkan observed variables yang membentuknya dapat diketahui jika kegigihan ini bermakna suatu pengerahan energi untuk melakukan usaha (kerja keras); juga merujuk kepada pilihan untuk mengerjakan tugas tersebut terlepas dari kesulitan, hambatan, atau bahkan situasi yang tidak menguntungkan.

Unsur kerja keras dan daya juang yang mendominasi komponen ini mengindikasikan kegigihan sebagai suatu bentuk kerja keras yang dilakukan individu untuk berjuang menyelesaikan apa yang ia mulai sampai selesai hingga mendapatkan apa yang ia inginkan. Ini dimaksudkan bahwa individu memiliki energi yang banyak untuk dikerahkan agar mampu terus bertahan dan berjuang pada usahanya. Individu yang gigih, memilih untuk menyelesaikan tugas atau kewajibannya hingga selesai, bahkan jika ia belum selesai ia tidak akan berhenti untuk mengerjakannya hingga mendapatkan apa yang ia inginkan. Ini juga merujuk kepada bagaimana individu bertahan untuk melewati kesulitan-kesulitan atau hambatan dengan atau tanpa usaha untuk mengatasinya (tekun) - namun ia akan tetap berupaya bertahan hingga kesulitan atau tantangan itu terlewatkan dengan sendirinya atau dengan upaya (adanya upaya menjadi tekun).

Kegigihan ini juga mengindikasikan sebuah bentuk kerelaan individu untuk berusaha - dimana ini merujuk pada suau 'kehendak' yang kemudian memotivasi individu untuk memberikan aksi atau tindakan atas apa yang ia inginkan. Adanya tujuan atau hasil tertentu yang ingin dicapai atau dapatkan membuat individu memiliki kerelaan untuk melakukan sesuatu dan mengerahkan energinya untuk berpusat pada tujuan tersebut. Ini mengenai kapasitas seseorang untuk bekerja dan menentukan sejauh mana seseorang dapat mengerahkan dirinya sendiri. Oleh karena itu kegigihan ini diartikan sebagai 
Jurnal Psikologi Terapan dan Pendidikan

ISSN: $2715-2456$

Vol. 1, No. 2, November 2019, pp. 143-181

sebuah kapasitas untuk pelepasan energi yang berkelanjutan dan ini dapat disamakan dengan daya tahan (Ryans, 1938). Disisi lain Woodworth dan Holt (Ryans, 1938) merujuk kegigihan sebagai sebuah "drive" yaitu energi fisik dan kimia yang disimpan oleh makhluk hidup dan dilepaskan karena stimulus tertentu.

Pengertian dan istilah yang disebutkan oleh peneliti tersebut menyimpulkan pandangan mereka bahwa kegigihan sebagai "drive" - mengakui "drive" hanya sebagai potensi jumlah energi yang dapat dilepaskan dalam salah satu dari sekian banyak saluran dan yang akan terus dirilis hingga keseimbangan makhluk hidup diperoleh kembali dan debut maksimum telah tercapai. Ini sebagaimana yang telah peneliti definisikan mengenai konsep dan makna dari kegigihan itu sendiri, yaitu energi. Pendapat ahli tersebut juga menegaskan bahwa kegigihan merujuk pada sebuah "komitmen" untuk mencapai tujuan. Dimana tujuan tersebut dapat berarti banyak hal - dapat sesuatu yang baik atau sesuatu yang sia-sia.

Disisi lain komponen kegigihan ini juga mengandung unsur profesionalitas, tangguh, juga tahan banting sebagai observed variables yang melengkapi aspek kegigihan dalam karakter siswa SMA ini mengandung makna sebagai bentuk kemampuan emosional untuk memproses komitmen atau pilihan setelah mempertimbangkan motif yang melatarbelakangi pilihan tersebut - untuk selanjutnya dikerjakan dengan mengerahkan energi untuk melakukan aksi mencapai tujuan atau hasil yang melatarbelakangi motif. Profesionalitas merujuk pada kapasitas individu untuk dapat bertindak "bijak" dalam mempertimbangkan motif yang mendorong individu untuk membentuk aksi atau tindakan - termasuk mempertimbangkan apakah akan mengizinkan diri mencapai tujuan dengan tindakan tertentu atau tidak apakah akan menyetujui tindakan atau mengabaikan. Profesionalisme ini sejatinya menyelaraskan motif yang melatarbelakangi suatu tindakan dengan nilai-nilai dan kemampuan yang ia miliki sehingga membentuk tujuan atau seperangkat hasil yang ingin dicapai atau didapatkan. Ini dikarenakan profesionalisme menunjukan integritas yang dimiliki seseorang. Dalam hal ini, profesionalisme akan membentuk seperangkat penilaian yang akan memberikan informasi pada diri mengenai berbagai pertimbangan-pertimbangan yang dapat menjadi dasar keputusan individu untuk seberapa besar memberi energi untuk mengejar tujuan, seberapa besar usaha untuk mencapai tujuan. Secara tidak langsung profesionalisme ini yang mendasari seberapa besar kegigihan yang ditunjukkan atau ditampilkan individu dan seberapa intens upaya individu tersebut.

Unsur tangguh dan daya tahan yang terdapat pada kegigihan menunjukkan besaran dan intensitas upaya yang dilakukan untuk mencapai tujuan atau hasil. Jika kerja keras dan daya juang merujuk pada energi yang dilepaskan untuk melakukan aksi, profesionalisme mendasari keputusan melakukan aksi dan upaya yang dilakukan serta membentuk seperangkat tujuan yang harus dicapai, dan terakhir tangguh dan tahan mengindikasikan kemampuan individu untuk bertahan dan teguh pada jalannya yang telah ia pilih 
Jurnal Psikologi Terapan dan Pendidikan

ISSN: $2715-2456$

Vol. 1, No. 2, November 2019, pp. 143-181

tersebut. Hal tersebut sejalan sebagaimana peneliti lain mendefinisikan kegigihan sebagai bentuk keterusan pelepasan energi dan pilihan untuk mempertahan energi yang menggerakan atau mendorong tindakan agar tercapai tujuan - seperti yang diungkapkan oleh Ryans (1983) bahwa kegigihan dan ketahanan fisik adalah hal yang sama dan keduanya merujuk kepada suatu tingkatan aktivitas umum.

Individu yang gigih pada dasarnya telah menunjukan karakter diri yang bertanggung jawab. Ia berusaha untuk menyelesaikan apa yang ia mulai, berusaha menanggulangi setiap masalah dan tantangan - baik dengan memberikan usaha untuk mengatasi masalah atau kesulitan yang muncul atau sekedar bertahan melewati masalah dan kesulitan tanpa usaha yang berarti - hingga ia mendapatkan apa yang ia inginkan. Individu yang memiliki kegigihan dalam dirinya sejatinya ia tidak akan mudah menyerah terhadap tantangan - terlebih didukung dengan ketekunan ini akan menjadi kolaborasi karakter yang baik untuk menghasilkan sesuatu yang lebih baik dan maksimal bahkan melampaui batas yang diinginkan. Namun ini hanya jika individu memiliki tujuan yang tepat untuk dipertahankan dan diperjuangkan - karena sejatinya tidak semua kegigihan mengarahkan pada tujuan yang tepat. Maka dari itu perlu kontrol diri yang baik untuk memilah apa yang tepat untuk dipertahankan dan diperjuangkan serta mana yang tidak.

Telah disebutkan sebelumnya bahwa kegigihan merujuk pada kemampuan individu untuk mengerahkan energinya dalam mengerjakan atau melakukan sesuatu - ini berarti menjaga agar usaha dengan energi tetap berjalan sama besar dan tidak mengalami kemunduruan. Namun sayangnya kegigihan tidak selalu berarti baik - kegigihan dapat saja menjadi pemborosan energi dan komitmen karena pencapaian yang diharapkan individu sia-sia belaka -bukan sesuatu yang bermaksud baik, ini bahkan hanya akan memberikan hasil yang negatif pula ketika pencapaian yang diinginkan juga sia-sia. Maka dari itu penting untuk menggunakan kegigihan secara bijak agar memberikan hasil yang efektif.

Individu yang gigih selalu ingin maju, meskipun tampak agak sedikit keras kepala karena tidak ingin ditentang, namun ia berorientasi pada prestasi atau tujuan yang ia dicapai - terlepas dari apapun tujuannya. Ini memberikan makna suatu komitmen individu untuk mengejar dan menyelesaikan tugas dan kewajiban mereka agar mendapatkan hasil yang diinginkan. Ini menjelaskan jika kegigihan merujuk pada individu yang hanya berusaha menyelesaikan tugas yang dihadapi untuk mengejar tujuan tertentu saja. Hal tersebut karena individu yang gigih biasanya mengerahkan kemampuannya untuk mengejar tujuan yang dapat dikelola dan memungkinkan mendapatkan hasil atau umpan balik langsung tanpa harus menunggu berlama-lama dengan mengorbankan banyak hal. Individu ini mampu bekerja lebih keras dengan mengerahkan energinya pada saat tertentu dan dalam waktu tertentu untuk sesuatu yang telah jelas baginya - terlebih ini tidak akan berlangsung dalam durasi lama melainkan ada batasan waktunya 
Jurnal Psikologi Terapan dan Pendidikan

ISSN: $2715-2456$

Vol. 1, No. 2, November 2019, pp. 143-181

tersendiri. Maka dari itu diperlukan lebih dari sekedar komitmen untuk membentuk karakter gigih yang baik bagi individu. Ini tidak hanya sekedar mendorong individu untuk lebih mampu mempertimbangkan tujuan yang akan dicapai berkaitan dengan komitmen yang akan ia lakukan. Disamping itu individu harus memiliki kontrol diri yang lebih baik lagi untuk dapat memilah tujuan-tujuan apa saja yang berharga yang pantas untuk diperjuangkan dan mana yang tidak.

Kegigihan ini memiliki keterkaitan terhadap beberapa aspek psikologis seperti self efficacy, self control, motivasi, juga self esteem (Peterson \& Seligman, 2003). Self efficacy membantu individu lebih dapat mempercayai bahwa ia memiliki kemampuan untuk dapat melakukan atau mengerjakan sesuatu. Ini memberikan suatu harapan positif bahwa ia bisa melakukan sesuatu dan mendapat hasil yang memuaskan, sehingga ini dapat meningkatkan kegigihan dari diri individu. Individu yang memiliki kemampuan yang tinggi seharusnya lebih mampu untuk bertahan pada tugas, pekerjaan, ataupun kewajiban mereka. Ini dikarenakan orang yang memiliki kemampuan tinggi mereka memiliki harapan keberhasilan yang tinggi pula dan mereka memiliki penilaian diri yang kuat pada diri mereka sehingga berusaha keras untuk tidak gagal.

Menurut peneliti, pada dasarnya kegigihan tidak dapat hanya ditentukan berdasarkan kompetensi yang dimiliki individu, meskipun kemampuan atau kompetensi yang dimiliki sedikit banyaknya dapat membantu individu dalam bertahan dan mempertahankan minat pada tugas tersebut sehingga ia akan berusaha untuk menyelesaikan pekerjaan hingga mencapai tujuannya. Oleh karena itu berkaitan dengan self efficacy ini menurut peneliti tidak hanya serta merta ditentukan oleh kompetensi yang ia miliki bahkan antara kompetensi yang dimiliki dengan kegigihan dapat saja berjalan tidak linear. Ini tergantung lagi pada bagaimana individu memandang dan memaknai suatu tugas, pekerjaan, ataupun kewajibannya. Sekalipun ia memiliki kompetensi, individu dapat saja tidak mengerahkan usaha yang maksimal dan justru bekerja sekedarnya saja - bahkan dibawah standar kemampuan yang ia miliki jika menurutnya tugas, pekerjaan, atau kewajiban tersebut tidak berarti banyak bagi dirinya, termasuk jika individu beranggapan telah atau akan ada orang yang mengerjakan pekerjaan tersebut dengan sungguh-sungguh. Adanya pemikiran tersebut mempengaruhi sikap dan tindakan individu yang jauh dari kegigihan ini dibuktikan dengan individu tersebut tidak mengeluarkan keseluruhan kemampuan ataupun energi untuk bersungguh-sungguh menyelesaikan apa yang harus ia selesaikan termasuk mempengaruhi tujuan apa yang ingin ia capai.

Hal ini juga diungkapkan dalam penelitian Locke (Peterson \& Seligman, 2003) dimana dari beberapa penelitian yang ia lakukan menunjukan adanya harapan hasil yang positif mampu meningkatkan kegigihan, dan sebaliknya harapan hasil yang negatif mengurangi kegigihan tersebut dan cenderung 
Jurnal Psikologi Terapan dan Pendidikan

ISSN: $2715-2456$

Vol. 1, No. 2, November 2019, pp. 143-181

membuat individu menarik diri dari tugas, pekerjaan atau kewajiban yang lain. Hal ini juga bergantung pada locus of control yang memotivasi tindakan individu. Ketika individu memiliki anggapan bahwa mereka dapat melakukan apa yang mereka lakukan, maka ini akan menggerakan mereka dan memberikan individu kekuatan untuk melakukan apa yang mereka ingin lakukan - ini jelas berkaitan dengan locus of control internal - yang menjadikan individu sebagai pusat kendali dalam hidupnya.

Disisi lain self esteem juga dikaitkan dengan kegigihan (Peterson \& Seligman, 2003). Ini dapat dijelaskan dengan harga diri membuat individu merasa harus melindungi dirinya terlebih jika adanya anggapan dari orang lain bahwa ia tidak mampu untuk melakukan sesuatu. Ini akan mendorong individu untuk berusaha keras mencapai tujuannya. Peterson dan Seligman (2003) bahkan menjelaskan bagaimana pola periku kegighan terkait adanya self esteem yang dimiliki individu. Peneliti tersebut menjelaskan bahwa individu cenderung tidak mengambil tugas yang mudah, ini dikarenakan tugas yang mudah tidak terlalu memberikan implikasi yang signifikan terhadap self esteemnya terlebih jika ia gagal melaksanakannya dengan baik - ini akan memberikan efek malu terhadap dirinya. Sebaliknya, berdasarkan penelitian dan pengamatan oleh Starnes dan Zinser (Peterson \& Seligman, 2003) individu cenderung memilih pekerjaan atau tugas yang sulit. Ini dikarenakan pekerjaan atau tugas yang sulit akan meningkatkan harga dirinya karena mengerjakan sesuatu yang sulit - ini dikarenakan sekalipun ia gagal itu tidak akan memberikan efek yang begitu mengancam terhadap harga dirinya.

Kegigihan berorientasi pada pencapaian tujuan. Ini mencerminkan suatu karakteristik individu yang gigih yaitu mereka memiliki motivasi untuk berprestasi yang mendorong dirinya untuk berprestasi dengan mencapai tujuannya. Adanya motivasi untuk berprestasi dalam diri individu menjadi karakteristik individu yang gigih. Ini dikarenakan individu yang memiliki ciri yang mengindikasikan bahwa individu berorientasi pada tujuan dan prestasi. Adanya keyakinan bahwa mereka mampu mengerjakan tugas, pekerjaan, dan kewajiban yang sulit, serta dengan adanya ekspektasi yang tinggi terhadap hasil yang akan ia capai membuat individu mengerahkan energinya berusaha untuk mendapatkan kesuksesannya.

Selain aspek-aspek tersebut terdapat pula aspek yang menentukan bagaimana kegigihan ini berkerja. Kontrol diri yang dimiliki individu menjadi sangat fundamen dalam menentukan sikap dan tindakan yang diambil individu - termasuk pilihan untuk gigih berusaha keras mencapai tujuan. Individu yang memiliki kontrol diri yang baik akan mampu mengarahkan sikap dan tindakannya untuk dapat menyelesaikan tugas, pekerjaan atau kewajibannya dengan baik terlepas apapun kesulitan dan rintangan yang menghalangi pencapaiannya. Ia tidak akan mudah tergoda atau bahkan putus asa atas pilihannya. Dalam hal ini kontrol diri mengambil peran untuk mengarahkan pikiran dan emosi membentuk kekuatan positif sehingga memberikan keyakinan terhadap kemampuan diri serta memberikan perasaan mampu dan 
Jurnal Psikologi Terapan dan Pendidikan

ISSN: $2715-2456$

Vol. 1, No. 2, November 2019, pp. 143-181

suasana hati yang positif untuk meneruskan komitmen mencapai tujuan dan bertahan sampai tujuan tersebut tercapai. Namun, ketika yang terjadi sebaliknya - individu kehilangan kontrol diri - maka akan memungkinkan individu kehabisan energinya sehingga membuat individu berhenti, menyerah atau putus asa ketika ia menemukan kesulitan dan hambatan. Hal ini dikarenakan kontrol diri juga berperan dalam penyediaan sumber daya energi bagi individu untuk bertahan dalam hidupnya.

Siswa SMA yang mengindikasikan adanya kegigihan dalam dirinya ia akan berusaha menjadi individu yang bertanggung jawab atas setiap tugas, pekerjaan dan kewajibannya baik sebagai siswa, anak, teman, tetangga, ataupun sebagai bangsa dan masyarakat Indonesia. Siswa memiliki tujuan yang jelas yang hendak dicapai. Ia berupaya untuk menyelesaikan setiap tugas, pekerjaan, dan kewajibannya tanpa menunda-menunda. Disisi lain siswa yang gigih mengindikasikan ia memiliki kepercayaan terhadap kemampuan yang ia miliki, sehingga ia berani untuk mengambil pilihan bertahan. Ini juga mengindikasikan siswa memiliki kontrol diri yang baik, ini dikarenakan ia mampu mengarahkan dirinya untuk menjalankan pilihan atau tujuan apa yang dirinya pilih.

Sama halnya dengan ketekunan, kegigihan memiliki peran yang sama penting dengan karakter tekun. Jika tekun membantu individu mengatasi masalah sehingga mendatangkan hasil yang memuaskan dan melebihi ekspektasi yang dibayangkan maka kegigihan membantu individu memberikan energi yang mendorong individu untuk berupaya dan bertahan hingga individu mencapai yang diinginkannya. Kegigihan memiliki arti penting bagi setiap individu terutama siswa SMA. Pada masa perkembangannya ini, remaja dihadapkan pada tugas untuk membentuk identitasnya. Keberhasilan-keberhasilan yang didapat siswa untuk meraih tujuannya bahkan untuk suatu tugas, pekerjaan, atau kewajiban yang berat akan memberikan rasa kepercayaan diri pada siswa bahwa ia memiliki kompetensi untuk menghadapi tantangan.

Disisi lain siswa mendapatkan kebanggaan dan kenikmatan pada keberhasilan sebelumnya, yang mana ini akan memacunya untuk meraih keberhasilan-keberhasilan berikutnya. Ini mengindikasikan bahwa keberhasilan telah membentuk atribusi yang positif sehingga mendorongnya untuk mengejar keberhasilan atau tujuan lain. Hal tersebut membantu remaja membentuk dan mengembangkan identitas "self" yang baik pada diri remaja. Kegigihan pada remaja akan berkembang semakin baik seiring dengan semakin meningkatnya usia - dimana dengan berkembangnya kemampuan kognitif dan emosional membantu mengendalikan diri (kontrol diri) secara bijak sehingga akan mengarahkan energinya untuk dilepaskan pada hal-hal dan tujuan yang tepat.

Komponen kegigihan yang menyusun karakter mandiri dalam skala ini memiliki standar penilaian dan interpretasi yang dapat dijelaskan dalam tabel 7 dibawah ini. 
Tabel 7.

Norma Hipotetik Komponen Kegigihan

\begin{tabular}{lc}
\hline \multicolumn{1}{c}{ Klasifikasi } & Skor \\
\hline Sangat gigih & $\geq 18$ \\
Gigih & $\geq 15-17$ \\
Cukup gigih & $\geq 10-14$ \\
Tidak gigih & $\geq 7-9$ \\
Sangat tidak gigih & $<7$ \\
\hline
\end{tabular}

Kategori Norma Hipotetik Komponen Gemar Belajar

Komponen gemar belajar yang menyusun karakter mandiri ini didefinisikan sebagai suatu kecenderungan yang merujuk pada kapasitas siswa yang memiliki ketertarikan dan keingintahuan yang tinggi terhadap ilmu pengetahuan, informasi, juga berbagai keterampilan yang ada disekitarnya dimana hal itu mendorong individu untuk senantiasa berupaya mengetahui dan mempelajari lebih dalam dan luas hal-hal yang menarik minatnya tersebut sehingga ini menunjukan suatu abilitas atau kompetensi yang dimiliki individu sekaligus mencerminkan kualitas diri sebagai pribadi yang cerdas. Berdasarkan definisi tersebut mengindikasikan ada beberapa karakteristik yang mencerminkan aspek karakter gemar belajar pada siswa, diantaranya yaitu: mengacu pada kapasitas siswa yang cenderung memiliki keingintahuan yang besar terhadap berbagai hal disekitarnya, mengacu kepada adanya perasaan positif dan menyenangkan untuk mempelajari sesuatu yang baru, serta mengacu pada kualitas diri yang unggul didasarkan pada kompetensi yang dimiliki oleh siswa.

Komponen gemar belajar ini merupakan komponen penting dalam karakter mandiri, dimana ini ditunjukan dengan nilai koefisien muatan faktor yang paling tinggi dan kuat antara observed variables dengan komponen pembentuknya. Komponen terdiri dari dari item-item belajar sepanjang hayat sebagai observed variables yang mendominasi komponen. Ini menunjukan juga bahwa komponen gemar belajar merupakan aspek dominan yang mendasari karakter mandiri siswa SMA dan menjadi aspek yang mencerminkan kemandirian pada siswa SMA.

Individu yang gemar belajar menunjukkan minat dan rasa ingin tahu yang tinggi terhadap berbagai hal yang terjadi disekitarnya. Ketertarikan ini dapat mengacu kepada sesuatu yang memiliki kapasitas kognitif seperti pengetahuan, wawasan ataupun keterampilan dan kompetensi tertentu. Ketertarikan tersebut mendorong individu untuk untuk memenuhi rasa keingintahuannya sehingga ia 
Jurnal Psikologi Terapan dan Pendidikan

ISSN: $2715-2456$

Vol. 1, No. 2, November 2019, pp. 143-181

berupaya untuk mencari tahu dan mempelajarinya dari sumber mana saja - selama sumber tersebut dapat dipercaya dan dipertanggungjawabkan atas konten yang disajikan.

Adanya upaya individu untuk mencari tahu sesuatu yang menarik minat mereka mencerminkan karakteristik kemandirian itu sendiri yaitu dengan menunjukan kegigihan untuk berupaya dan ketekunan untuk mempelajari pengetahuan dan keterampilan. Hal tersebut dikarenakan mereka termotivasi untuk memperoleh keterampilan atau pengetahuan baru yang dapat menambah keahlian atau kompetensi dirinya. Individu yang gemar belajar tidak akan setengah-setengah untuk mengetahui atau memahami sesuatu yang menarik minatnya, melainkan ia akan berusaha untuk mempelajarinya secara mendalam sehingga ia memiliki wawasan yang luas mengenai pengetahuan atau keterampilan yang menarik minatnya tersebut dan bahkan terkadang melebihi apa yang diketahui orang-orang.

Disisi lain kegemaran belajar ini juga mengindikasikan adanya kesenangan atau munculnya perasaan positif ketika mengetahui atau mempelajari hal-hal yang baru - sekalipun terkadang ini juga dapat memberikan implikasi munculnya rasa frustasi bagi individu karena hal tersebut menjadi lebih menantang untuk dipahami atau dipelajari. Meski demikian, hal tersebut bukanlah sesuatu yang berarti signifikan, melainkan salah satu emosi yang sering muncul ketika seseorang memiliki ketertarikan terhadap sesuatu - sama halnya dengan rasa semangat ketika mengetahui sesuatu menguasai individu. Inidividu yang gemar belajar mereka terlalu haus akan pengetahuan disekitarnya. Ia selalu ingin mengetahui apa yang sedang terjadi disekitarnya, mengetahui cara sesuatu ada dan bekerja.

Individu yang gemar belajar mereka selalu memiliki waktu untuk mencari tahu dan mempelajari hal-hal yang ingin diketahuinya. Hal ini dikarenakan ia harus menuntaskan rasa ingin tahunya atas pengetahuan, informasi ataupun keterampilan tertentu yang menarik minatnya. Mereka tahu bagaimana cara memenuhi rasa ingin tahunya. Ia senang menghabiskan waktu berjam-jam membaca buku atau literatur apapun, mendengarkan atau menontoh video apapun yang dapat memenuhi rasa keingintahuannya. Ada rasa puas dan kesenangan pada individu ketika menenggelamkan diri pada aktivitas tersebut yang mana itu dapat memberikan kesenangan yang sama saat berkumpul bersama teman-teman seperti kebiasaan remaja pada umumnya. Individu selalu memiliki banyak pertanyaan akan sesuatu disekitarnya sehingga tak jarang hampir sebagian besar waktunya ia habiskan untuk mencari tahu jawaban akan pertanyaannya. Terkadang, bahkan individu tidak hanya cukup dengan beberapa fakta atau ilmu yang ada, sehingga ia selalu berusaha mencari tahu lebih banyak dan mendalam akan hal-hal tersebut. Ini memberikan pengetahuan dan wawasan yang luas bagi individu. Selain itu biasanya mereka selalu dapat mengelaborasikan dan mengintegrasikan pengetahuan-pengetahuan dan informasi-informasi 
Jurnal Psikologi Terapan dan Pendidikan

ISSN: $2715-2456$

Vol. 1, No. 2, November 2019, pp. 143-181

yang ia ketahui sehingga menjadi satu kesatuan utuh yang menjelaskan suatu hubungan sebab akibat akan suatu hal. Suatu hal yang mana dapat memperkaya individu dalam segi wawasan pengetahuannya.

Karakter gemar belajar memiliki implikasi yang positif terhadap diri individu. Hal ini dikarenakan gemar belajar mencerminkan kualitas diri siswa sebagai pribadi yang unggul. Ini tidak hanya berkaitan dengan kapasitas kognitif sebagai proses yang melatarbelakangi luasnya pengetahuan dan wawasan individu, melainkan juga karena individu mampu mengendalikan aspek emosional mereka. Individu dapat mengendalikan dirinya untuk tetap teguh dan gigih dalam memenuhi rasa keingintahuannya, tahu bagaimana mengendalikan rasa frustasinya yang biasanya sering muncul saat individu belajar, tidak takut akan kegagalan atau kesulitan yang mungkin ia hadapi dalam usahanya. Hal tersebut dikarenakan motivasi untuk mengetahui hal-hal baru tersebut lebih besar sehingga mendorong dan membuatnya mampu tetap bertahan sekalipun dihadapkan pada kesulitan, tantangan, dan bahkan adanya umpan balik yang negatif dari orang-orang disekitarnya. Selain itu, individu tidak pernah merasa bosan - melainkan ia selalu merasa tertantang untuk mengetahui hal-hal yang menarik minatnya. Ia selalu merasa mampu dan yakin dengan pengetahuan yang ia miliki sehingga ia memiliki keyakinan untuk dapat melakukan sesuatu dengan baik. Belajar sejatinya tidak hanya mengenai pelajaran umum disekolah seperti matematika, ipa, dan lainnya namun dapat juga hal-hal yang tidak dipelajari di sekolah secara mendalam dan menarik minat individu seperti misal astronomi, pemrograman, desain visual, gizi dan kesehatan, kesehatan jasmani, trend pakaian dan kecantikan, serta ilmu apapun itu. Ini karena ada banyaknya pengetahuan, informasi, dan keterampilan yang sangat berguna dan perlu diketahui individu dan berguna dalam menjalankan kehidupan.

Individu yang gemar belajar tidak hanya menunjukkan ia sebagai pribadi cerdas yang memiliki wawasan luas saja, lebih daripada itu keluasan dan kedalaman pengetahuan itu membantu individu untuk dapat berpikiran terbuka serta mampu melihat dan menilai sesuatu dari perspektif yang lain. Ini menunjukkan kualitas diri individu yang memiliki toleransi yang tinggi terhadap berbagai perbedaan dan mampu untuk bertindak lebih objektif serta adil terhadap berbagai hal yang terjadi disekitarnya. Keluasan dan kedalaman pengetahuan yang dimiliki individu membantu ia dalam membentuk nilai, mengarahkan sikap dan tindakan dalam menjalankan kehidupan. Hal itu karena aktualisasi tertinggi dari pengetahuan dan wawasan yang dimiliki individu adalah ia mampu bersikap objektif, mengetahui apa yang benar dan salah atas tindakan apa yang dilakukan sehingga mampu menggunakan dan mengimplementasikan ilmu yang miliki dengan efektif. Pengetahuan tidak akan berguna jika individu tidak memiliki nilai moral yang baik dan mentaatinya - sebaliknya tanpa pengetahuan yang cukup, individu dapat saja kalah dengan komitmen nilai-nilai moralnya, itu karena ia tidak memiliki pengetahuan yang cukup untuk menguatkan 
Jurnal Psikologi Terapan dan Pendidikan

ISSN: $2715-2456$

Vol. 1, No. 2, November 2019, pp. 143-181

nilai moral tersebut. Pengetahuan sejatinya membuat individu menjadi lebih bijak dalam bersikap dan berperilaku. Individu tidak akan mudah terpengaruh stereotip umum yang tidak berlandaskan ilmu pengetahuan (tidak masuk diakal). Keluasan dan kedalaman pengetahuan dan wawasan membuat individu memiliki standar nilainya sendiri yang membantu individu untuk dapat bertindak objektif dan membuat keputusan yang tepat.

Mempelajari sesuatu tidak akan pernah sia-sia. Segala ilmu memiliki manfaat bagi individu dan kehidupan, hanya jika individu mampu menggunakan dan memanfaatkan ilmu tersebut secara bijak. Telah disebutkan pengetahuan tidak hanya sebatas mempelajari pelajaran di sekolah agar individu mendapatkan nilai atau prestasi yang baik disekolah. Pengetahuan atau wawasan mungkin tidak menghasilkan pencapaian langsung atau manfaat langsung seperti mempelajari pelajaran sekolah. Seiring berprosesnya waktu dan semakin mapannya individu memahami suatu ilmu - ia dapat mengembangkan ilmu pengetahuan yang lebih dalam dan luas lagi sehingga individu memberikan kontribusi yang substansial terhadap pengembangan ilmu tersebut. Disisi lain dengan kemampuan individu menguasai teknologi dan keterampilan tertentu, ia dapat mengemas dan membuat inovasi agar setiap individu dapat memahami suatu pengetahuan atau keterampilan dengan cara yang lebih mudah dan menyenangkan. Ini merupakan aktualisasi tertinggi dari memiliki pengetahuan dan wawasan yang luas dan dalam yaitu mendorong dirinya untuk dapat menghasilkan sesuatu yang berguna bagi masyarakat - suatu kemampuan berinovasi yang turut mengindikasikan keunggulan individu sebagai pribadi tunggal juga bagian dari suatu bangsa.

Sejatinya gemar belajar belum terlalu mendapatkan perhatian sebagai sebuah kekuatan karakter utama seperti karakter kejujuran, keadilan, rendah hati dan lainnya. Gemar belajar oleh sebagian besar peneliti dimasukkan sebagai deskriptor parsial dari konstruk lain sehingga cenderung menjadi bagian dari subskala dan bukan menjadi konstruk utama yang memiliki pengukuran sendiri (Peterson \& Seligman, 2003). Diantara peneliti tersebut salah satunya adalah Peterson dan Seligman yang menjadikan karakter cinta belajar sebagai karakter utama dalam skala VIA-IS yang mereka kembangkan, dan hal itu masih terus dikaji. Namun dalam konstruksi skala karakter mandiri siswa SMA ini, secara empiris didapatkan bahwa gemar belajar menjadi salah satu karakter utama yang menyusun dan membentuk karakter mandiri.Oleh karena itu gemar belajar merupakan salah satu karakter utama yang penting dalam pengembangan individu dan bangsa Indonesia.

Ada beberapa aspek yang dapat menjelaskan latar belakang aspek gemar belajar dalam diri individu. Individu yang gemar belajar dapat dilihat melalui orientasi motivasinya dalam mempelajari sesuatu atau terlibat dalam suatu kegiatan tertentu. Telah diketahui bahwa motivasi adalah suatu dorongan 
Jurnal Psikologi Terapan dan Pendidikan

ISSN: $2715-2456$

Vol. 1, No. 2, November 2019, pp. 143-181

atau alasan yang melatarbelakangi seseorang melakukan sesuatu. Motivasi yang menggerakkan individu untuk belajar dapat yang berasal dari luar atau dari dalam diri individu itu sendiri. Umumnya individu yang memiliki kegemaran dalam belajar mereka memiliki motivasi instrinsik dalam mempelajari hal-hal tersebut. Ini dikarenakan mereka secara sadar dan aktif merasakan kebutuhan dan kesenangan dengan mempelajari hal-hal baru tersebut - dan bukan sesuatu yang didorong oleh orang lain atas komponsasi tertentu. Motivasi intrinsik ini membuat individu memiliki afeksi positif terhadap pelajaran dan membuatnya secara aktif berupaya mempelajari hal-hal yang menarik minatnya dengan tekun dan gigih.

Disisi lain adanya minat pribadi terhadap suatu pengetahuan atau keterampilan membuat individu mengarahkan energinya untuk mempelajari lebih dalam dan luas mengenai ketertarikan tersebut. Adanya minat pribadi terhadap suatu pengetahuan atau keterampilan menegaskan jika ketertarikan ini tidak hanya merujuk pada hal-hal universal yang sering bersinggungan dengan kehidupan individu saat ini seperti misalnya pelajaran sekolah - melainkan mempelajari suatu topik, pengetahuan, informasi, dan keterampilan tertentu dengan lebih mendalam dan spesifik - sehingga individu memiliki pengetahuan yang konkrit dan luas terhadap topik, pengetahuan, informasi, dan keterampilan tersebut.

Gemar belajar pada dasarnya bukan berarti mendorong individu untuk menguasai atau menjadi ahli terhadap berbagai pengetahuan, informasi, dan keterampilan yang ada. Individu yang gemar belajar dan memiliki ketertarikan tertentu terhadap sesuatu akan berusaha mencari tahu hal-hal penting yang berkaitan dengan hal tersebut - mungkin bukan yang membuat individu menjadi ahli atau menguasai hal tersebut karena jelas ada banyak pengetahuan dan keterampilan yang berguna didunia ini, sedangkan individu memiliki kapasitas kemampuan dan ketertarikannya masing-masing. Meski demikian, terhadap pengetahuan atau wawasan umum dan universal - individu yang gemar belajar juga senang mencari tahu dan mempelajarinya sehingga iamemiliki pengetahuan yang cukup dari apa yang dapat dipahami oleh orang-orang awam. Ini dikarenakan individu yang gemar belajar selalu merasa ingin tahu terhadap banyak hal yang terjadi disekitarnya sehingga ia tetap berusaha untuk selalu terinformasi meski bukan untuk menguasainya - namun cukup untuk memiliki pengetahuan mengenai hal tersebut.

Hal itu menjelaskan mengapa gemar belajar berkaitan erat dengan minat atau ketertarikan pribadi setiap individu terhadap suatu pengetahuan atau keterampilan. Itu dikarenakan minat pribadi tersebutlah yang menjadi motivasi individu untuk mempelajari dan mengeksplorasinya - bahkan sampai seluas dan sedalam informasi yang dapat menjelaskan hal yang menarik minatnya. Individuakanmemiliki rasa semangat dan positif dalam mempelajarinya serta berusaha maksimal mengerahkan segala kemampuannya dan bertahan menghadapi kesulitan atau tantangan dalam mempelajari hal yang menarik minatnya tesebut. 
Jurnal Psikologi Terapan dan Pendidikan

ISSN: 2715-2456

Vol. 1, No. 2, November 2019, pp. 143-181

Setiap individu adalah manusia yang unik dan memiliki ketertarikan yang berbeda-beda terhadap suatu hal termasuk jenis pengetahuan atau keterampilan. Individu yang memiliki ketertarikan terhadap suatu pengetahuan dan keterampilan ia akan belajar sungguh-sungguh untuk dapat menguasainya - selain karena hal tersebut mendatangkan suatu kesenangan dan kepuasan tersendiri bagi dirinya. Dengan bersungguh-sungguh mempelajari hal-hal yang menarik minatnya tersebut memberikan suatu keahlian dan kompetensi baru bagi individu. Kompetensi yang dimiliki individu atas pengetahuan dan keterampilan yang ia miliki mengindikasikan kemampuan individu untuk mengendalikan dirinya agar dapat menguasai hal yang menarik minatnya tersebut - dimana ini adalah karakteristik dari individu yang selalu berorientasi pada keberhasilan. Ia tidak akan membiarkan dirinya mengalami kegagalan untuk mempelajari sesuatu yang menarik minatnya - ia akan berupaya mengatasi kesulitan tersebut dan berusaha keras mempelajarinya termasuk mengendalikan rasa frustasi yang muncul ketika mempelajarinya.

Seperti yang diungkapkan oleh Peterson dan Seligman (2003) dalam penjelasan karakter cinta belajar mereka dalam skala karakter VIA-IS, mereka mengungkapkan jika untuk merasakan cinta belajar, para peneliti menyarankan untuk mempelajari suatu kompetensi- individu harus mampu merasakan rasa kompetensi dan keyakinan akan kemampuan diri dalam proses belajar: dimana ini mengacu kepada mereka harus dapat merasakan dan mengetahui bahwa mereka mampu untuk menguasai suatu pengetahuan atau keterampilan, mengisi kekosongan dalam pengetahuan mereka, dan lainnya.

Gemar belajar sangat penting dimiliki oleh siswa SMA. Ini akan memacu siswa untuk memiliki ketertarikan terhadap berbagai hal yang ada disekitarnya dan mempelajarinya dengan senang hati. Individu yang gemar belajar akan mengembangkan karakter ketekunan dan kegigihan dalam belajar, ia tidak mudah bergantung pada orang lain dan selalu berusaha sendiri. Ia memiliki tujuan yang jelas atas apa yang akan dilakukan dan tidak mudah menyerah. Siswa memiliki pengendalian diri yang baik - ia tahu bagaimana cara mengendalikan situasi dan melakukan upaya untuk bertahan dan berjuang dalam belajar, misalnya mengendalikan rasa frustasi atau hambatan apapun yang muncul, termasuk membuat belajar menjadi lebih menarik. Siswa yang gemar belajar juga memiliki kepercayaan dan keyakinan terhadap kemampuannya.

Disisi lain masa SMA adalah masa siswa untuk mempelajari berbagai hal sebagai bentuk kompetensi dan modal untuk memasuki tahapan jenjang berikutnya dimana mereka akan mengambil tanggung jawab dan peran individu dewasa. Pengetahuan dan keterampilan yang mereka pelajari sedari dini akan membantu mereka dalam membentuk dan mengembangkan dirinya. Ini karena gemar belajar menjadi suatu kompetensi yang memiliki dampak langsung terhadap karakter individu. Dengan 
Jurnal Psikologi Terapan dan Pendidikan

ISSN: $2715-2456$

Vol. 1, No. 2, November 2019, pp. 143-181

mengembangkan karakter aspek gemar belajar akan membuat individu senantiasa berorientasi pada tujuan dan keberhasilan serta memiliki rasa semangat untuk mempelajari hal-hal yang ada disekitarnya. Hal itu akan membuat siswa yang gemar belajar akan lebih mampu berkomitmen dengan tugas-tugas sekolah mereka menyukai dan merasa senang terlibat dalam tugas dan kegiatan sekolah.

Disamping itu dengan kompetensi yang mereka miliki, membuat individu yang gemar belajar memiliki prestasi yang tinggi sebagai hasil dari perjuangannya sehingga ia akan memiliki keberhasilan dalam karirnya. Selain itu Covington (Peterson \& Seligman, 2003) menyebutkan jika cinta belajar akan memberikan kesejahteraan fisik dan psikologis, sementara itu Csikszentmihalyi (Peterson \& Seligman, 2003) juga menyebutkan jika cinta belajar dapat mendukung adanya pengalaman positif dalam menjalankan kehidupan. Ini dikarenakan gemar belajar akan membuka wawasan individu untuk mengetahui dan mengalami berbagai hal. Hal tersebut merupakan kualitas keunggulan yang harus dimiliki setiap individu terutama siswa yang sedang berada pada masa pengembangan diri.

Komponen gemar belajar yang menyusun karakter mandiri dalam skala ini memiliki standar penilaian dan interpretasi yang dapat dijelaskan dalam tabel 8 dibawah ini.

Tabel 8.

Norma Hipotetik Komponen Gemar Belajar

\begin{tabular}{lc}
\hline \multicolumn{1}{c}{ Klasifikasi } & Skor \\
\hline Sangat gemar belajar & $\geq 11$ \\
Gemar belajar & $\geq 9-10$ \\
Cukup gemar belajar & $\geq 6-8$ \\
Tidak gemar belajar & $\geq 4-5$ \\
Sangat tidak gemar belajar & $<4$ \\
\hline
\end{tabular}

\section{KESIMPULAN}

Dari hasil kontruksi alat ukur psikologi karakter mandiri siswa menengah atas memiliki properti psikometris yang baik dan memuaskan. Alat ukur ini menghasilkan 16 item pernyataan yang memiliki validitas dan reliabilitas yang baik. Dari hasil uji validitas faktorial principal component analysis didapatkan bahwa dari 8 komponen yang diprediksi oleh peneliti, item-item tersebut mengumpul pada 3 komponen utama pembentuk konstruk skala. item-item tersebut mengumpul dengan komponen pembentuknya yaitu komponen ketekunan sebanyak 8 item, komponen kegigihan sebanyak 5 item, serta komponen gemar belajar sebanyak 3 item. Nilai koefisien korelasi antar item dalam muatan faktor bergerak dari skor 0.447 sampai dengan 0.779 yang berarti item dapat merefleksikan dengan baik individu yang memiliki karakter mandiri dan tidak. Berdasarkan hasil analisis korelasi komponen 
Jurnal Psikologi Terapan dan Pendidikan

ISSN: $2715-2456$

Vol. 1, No. 2, November 2019, pp. 143-181

diketahui jika antar komponen pada konstruk skala karakter mandiri ini tidak saling mengikat, masingmasing komponen berdiri sendiri dan tidak saling mempengaruhi.

Hasil uji reliabilitas menggunakan metode Gutmann's memiliki koefisien 0.820 yang berarti skala ini memiliki nilai reliabilitas yang cukup dan baik untuk dapat mengukur karakter mandiri dengan digunakan berdampingan dengan alat ukur pendukung asesmen karakter ini. Penelitian selanjutnya diharapkan dapat melakukan penelitian terhadap individu dewasa seperti mahasiswa atau pekerja. Mengingat pentingnya karakter mandiri sebagai penentu keberadaban dan kehebatan bangsa Indonesia maka perlu adanya kontruksi skala karakter mandiri yang tidak hanya ditujukan bagi anak-anak, namun juga untuk remaja dan individu dewasa. Dengan adanya kelanjutan dalam pengembangan skala karakter mandiri ini diharapkan dapat mengukur dan mengevaluasi karakter mandiri bangsa Indonesia secara keseluruhan sehingga dapat mengetahui standar dan mengevaluasi mandiri bangsa Indonesia. Selain itu dalam konsep karakter mandiri diharapkan penelitian lain dapat mengembangkan dan menguji adanya kaitan antara keimanan dan kebermaknaan individu terhadap Ketuhanan Yang Maha Esa memiliki implikasi terhadap karakter individu sehingga dapat dikontruksikan dan menjadi bagian yang terintegrasi dalam pengukuran karakter mandiri.

\section{DAFTAR PUSTAKA}

Allmark, P. J. (2008). An Aristotelian account of autonomy. Journal of Value Inquiry. 42(1), 41-53.

Anggoro, W. J., \& Widhiarso, W. (2010). Konstruksi dan Identifikasi properti psikometris instrumen pengukuran kebahagiaan berbasis pendekatan indegenous psychology: Studi multitraitmultimethod. Jurnal Psikologi, 37(2), 176-188.

Azwar, S. (2017). Penyusunan skala psikologi. Yogyakarta: Pustaka Pelajar.

Chaplin, J. P. (2006). Kamus lengkap psikologi. Jakarta: PT. Raja Grafindo Persada.

Duckworth, A. L., Peterson, C., Matthews, M. D., \& Kelly, D. (2007). Grit: Perseverance and passion for long-term goals. Journal of Personality and Social Psychology, 96(6),1087-1101.

Harrington, D. (2009). Confirmatory factor analysis pocket guide to social work research methods. New York: Oxford University Press.

Haryanto. (2011). Pendidikan karakter menurut Ki Hadjar Dewantara. Cakrawala, 30, 15-27.

Hurlock, E. (2014). Psikologi Perkembangan: Suatu pendekatan sepanjang rentang kehidupan edisi kelima. Jakarta: Erlangga.

Josephson, M. (2002). www.JosephsonInstitute.org www.CharacterCounts.org Making Ethical Decisions. (W. Hanson, Ed.). Los Angeles: Josephson Institute of Ethics.

Liu, C., \& Bates, T. (2014). The structure of attributional style: Cognitive Styles and optimism-pessimism bias in the attributional style questionnaire. Personality and Individual Differences, 66, 79-85. 
Jurnal Psikologi Terapan dan Pendidikan

ISSN: $2715-2456$

Vol. 1, No. 2, November 2019, pp. 143-181

Masrun, M. (1986). Penelitian studi mengenai kemandirian pada penduduk di tiga suku bangsa (Jawa, Batak, Bugis). Laporan Penelitian. Yogyakarta: Fakultas Psikologi Universitas Gadjah Mada.

Meriam, W. (2019). Search Engine Definition. Merriam-Webster Online Dictionary. Diakses pada 20 Juni 2019, dari https://www.merriam-webster.com/dictionary/self-reliance.

Periantalo, J. (2015). Validitas alat ukur psikologi aplikasi praktis. Yogyakarta: Pustaka Pelajar.

Peterson, C., \& Seligman, M. (2003). Character strengths and virtues a handbook and classification. New York: Oxford University Press, Inc.

Ryans, G. G. (1938). The meaning of persistence. The Journal of General Psychology, 19(1), 79-96.

Santrock, J. W. (2009). Remaja edisi 11 jilid 1. Jakarta: Erlangga.

Stott, Leland H. (1938). An analytical study of self-reliance. The Journal of Psychology: Interdiscipliary and Apllied. 5(1), 107-118.

Tabachnick, B. G., \& Fidell, L. S. (2014). Using multivariate statistics sixth edition. Boston: Pearson.

Taqwiem, A. (2018). Urgency of character education based on multiculturalism. Advances in Social Sciences, Education and Humanities Reseacrh (ASSEHRA), 147, 10-13. 